\title{
TWO NEW SPECIES OF PLEUROTHALLIS (ORCHIDACEAE: PLEUROTHALLIDINAE) ALLIED TO P. CARDIOTHALLIS, WITH A NOTE ON FLOWER ACTIVITY
}

\author{
Franco Pupulin ${ }^{1-3,5}$, Melissa Díaz-Morales ${ }^{1}$ Jaime Aguilar $^{1}$ \& Melania Fernández Me $^{1,4}$ \\ ${ }^{1}$ Jardín Botánico Lankester, Universidad de Costa Rica. P.O. Box 302-7050 Cartago, Costa Rica. \\ ${ }^{2}$ Harvard University Herbaria, Cambridge, MA, U.S.A. \\ ${ }^{3}$ The Marie Selby Botanical Gardens, Sarasota, FL, U.S.A. \\ ${ }^{4}$ Department of Plant \& Soil Science, Texas Tech University, Lubbock, TX, U.S.A. \\ ${ }^{5}$ Author for correspondence: franco.pupulin@ucr.ac.cr
}

\begin{abstract}
Two new species of Pleurothallis subsection Macrophyllae-Fasciculatae from Costa Rica, allied to $P$. cardiothallis, are described and illustrated, and their relationships discussed. Pleurothallis scotinantha is compared with $P$. oncoglossa, from which it can be easily distinguished by the concolorous, dark purple flowers, the distinctly deflexed petals, and the lip without a distal callus that is not hooked at the apex. Pleurothallis navisepala, from the northern Costa Rican cordilleras, is compared with P. cardiothallis, from which it is distinguished by the simultaneous flowering of two or more flowers, the much smaller size of the flowers, and the deeply navicular sysnsepal, which prevents complete spreading of the flower. A key to the Costa Rican species of the group is presented. Observations on floral behavior in the species allied to $P$. cardiothallis are provided and the possible function of this behavior is discussed. The visit of a tephritid fly to the flowers of $P$. navisepala is described.
\end{abstract}

KEY wORDs: flora of Costa Rica, new species, Pleurothallidinae, Pleurothallis cardiothallis group, Tephritidae

Introduction. Pleurothallis cardiothallis Rchb.f. has been traditionally interpreted as a single, "variable species", with broad geographical distribution. Virtually any specimen with tall habit, a large, cordiform leaf, and a flower that is small compared to the size of the plant but relatively large compared to most species of Pleurothallis in Central America, has been classified as belonging to this species. In order to discuss, hereafter, the taxonomy of the species related to $P$. cardiothallis, we have to briefly summarize the history of this species and clarify its currently accepted interpretation, as it is relevant to the understanding of the identity of Costa Rican populations treated under this name.

Heinrich Gustav Reichenbach (1857) described Pleurothallis cardiothallis from a plant cultivated in the collection of Gustav Wilhelm Schiller (18031870) at Ovelgönne, not far from Hamburg, which was imported from England without data about its original provenance. Schiller grew orchids from several tropical American countries, including Brazil (i.e., types of
Cattleya schilleriana Rchb.f. and Octomeria lobulosa Rchb.f.), Colombia (type of Lycaste schilleriana Rchb.f.), Dominican Republic (type of Epidendrum isochilum Rchb.f.), Guatemala (type of Epidendrum strophinx Rchb.f.), Mexico (types of Hexadesmia rhodoglossa Rchb.f., Ornithidium histrionicum Rchb.f., Ponera dubia Rchb.f., among others), and Costa Rica (type of Stanhopea costaricensis Rchb.f.). Reichenbach eventually described 42 species and varieties from his collection (Jenny 2015), and the probability of ascertaining the original country where Schiller's specimen was collected is almost zero. No flowers wee even conserved in the type specimen, which only consists of three detached ramicauls with leaves, one of which bears the remnants of a flower pedicel (W-R 25498). Our understanding of the flower morphology is therefore limited to the quite synthetic protologue, together with a crude drawing of the flower and a floral analysis made by Reichenbach himself, kept in his herbarium in Vienna (Fig. 1A). Vegetatively, 

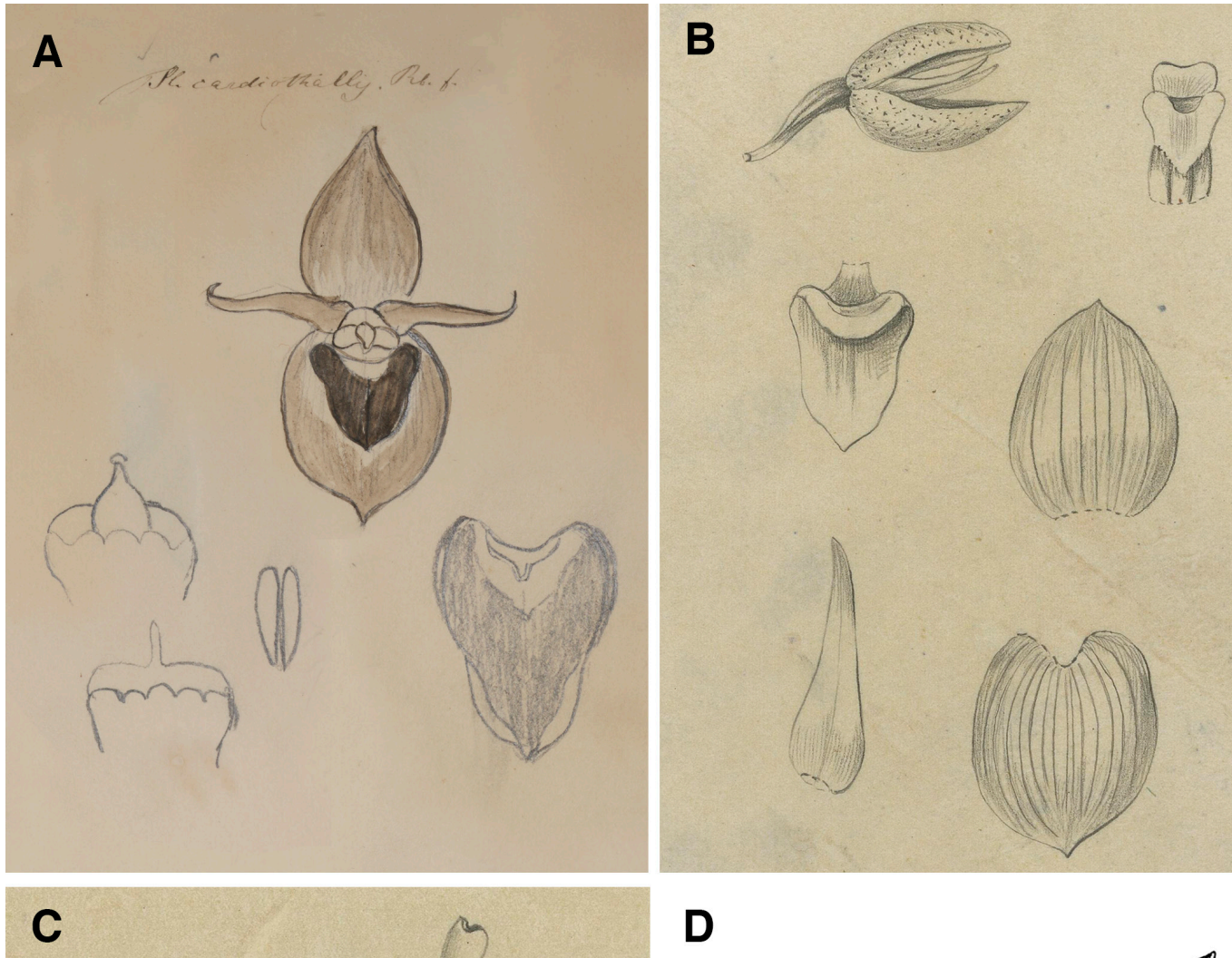

C
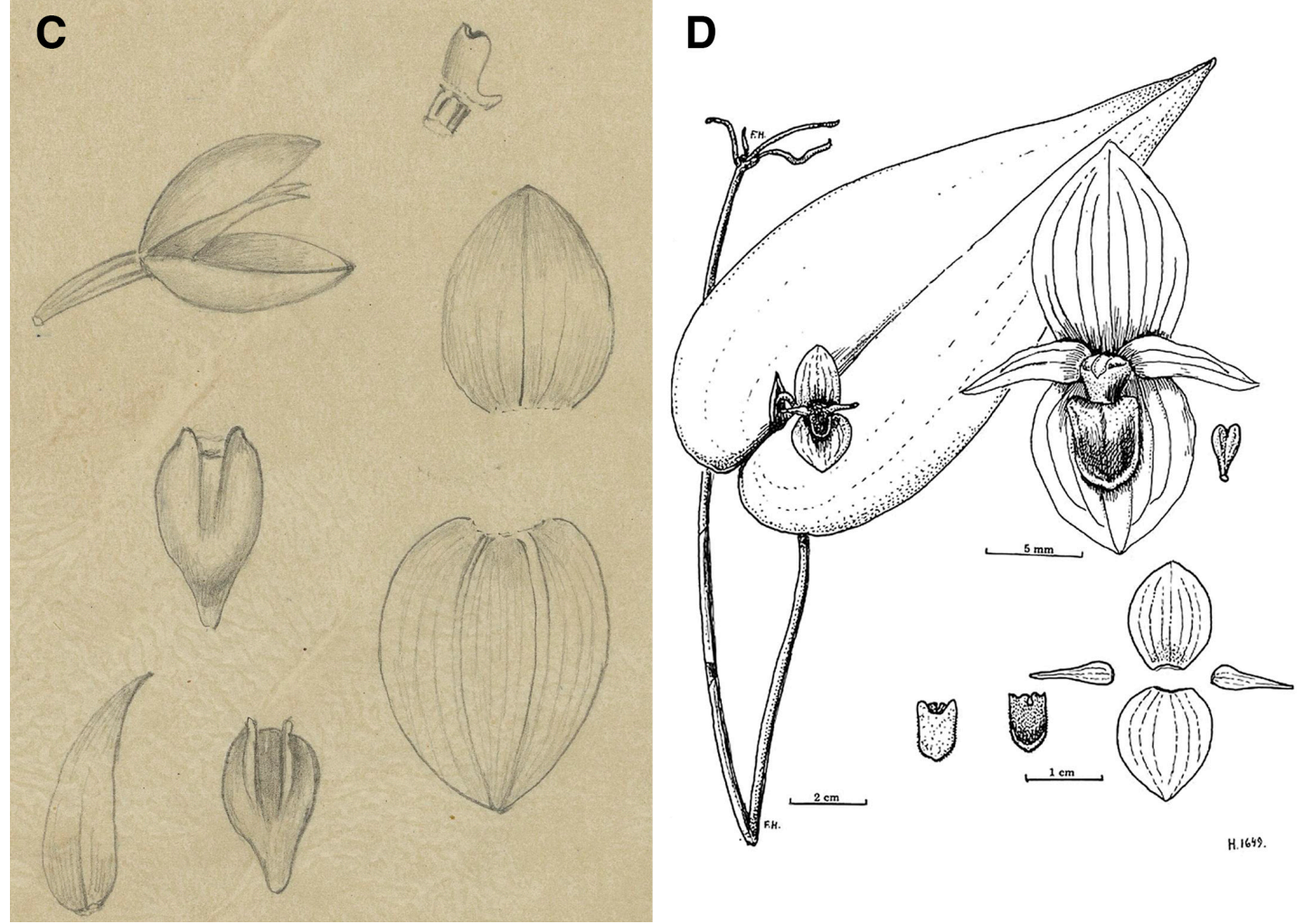

LANKESTERIANA 17(2). 2017. (C) Universidad de Costa Rica, 2017. 
Reichenbach compared the new species to his $P$. cardiostola (a comparison that in turn is made difficult by the number of different taxa that Reichenbach included under this name in his herbarium), and this must mean that the type specimen was a relatively tall plant. With no measurements indicated in the description, and no scale on the drawings, we can only speculate about the size of the flower, but the choice of $P$. cardiostola for the comparative diagnosis could mean that the flowers were comparable in size to that species. This excludes most of the small-flowered species, mostly reduced in habit size, belonging to the so-called group of the "frog" Pleurothallis. Reichenbach described the lip as heart-shaped (but it is illustrated as shield-shaped), half the size of the sepals in length. The flower color is stated as brown on a green base (Reichenbach 1857). The sketches by Reichenbach clearly illustrate a flower with a peltate lip, with the distal margins recurved, and subfalcate, narrowly linear-lanceolate petals (Fig. 1A). All the remaining materials that Reichenbach identified as P. cardiothallis, conserved in his herbarium, were originally collected and illustrated in Costa Rica by August R. Endrés (1838-1874) (Pupulin et al. 2013).

In the absence of exact geographic indications of the original collection, and in the absence of actual flower material for examination, a positive identification of $P$. cardiothallis was precluded and the interpretation of this concept had to be somewhat speculative. Hemsley (1884) included P. cardiothallis in his account on the orchids of Central America on the basis of a Nicaraguan collection by Charles Wright (1811-1885), originally quoted by Lindley in the treatment of Pleurothallis for his Folia Orchidacea (Lindley 1859) (Wright 12, K). We have not examined this specimen. Ames (1937) interpreted P. cardiothallis as a species ranging from Guatemala to Costa Rica, and referred Costa Rican material to the type collection of P. costaricensis Schltr., non Rolfe ( $\equiv P$. schlechteriana Ames), an interpretation disputed by Pupulin and collaborators (2016). By the time Ames published his contribution for Paul Standley and Dahlgren's Flora of Costa Rica, he also had at hand a specimen collected by Standley and Juvenal Valerio Rodríguez (19001971) in 1926 in the Central Volcanic Cordillera of Costa Rica (AMES 32023). Louis O. Williams (1951) included Mexican material with the sepals longer than $1 \mathrm{~cm}$ under the concept of $P$. cardiothallis. Ames and Correll (1952) treated P. cardiothallis as a widespread and variable species ranging from Mexico to Costa Rica, and provided its first modern description, based on material from Guatemala.

Rolfe (1892) first segregated P. subulata from a plant grown in Peckau, Bohemia, by Baron Josef Hruby de Geleny (1866-1943), without data about its original collecting locality. The herbarium at $\mathrm{K}$ conserves the holotype flower (K 584128), which shows quite large sepals (to $14 \times 10 \mathrm{~mm}$ ) and a peltate lip with the apical margins inflexed (Fig. 2). The petals are apparently short on the holotype flower, but a second specimen sent by Hruby (K 584129) has petals almost $7 \mathrm{~mm}$ long. This second specimen also has part of a stem with a large leaf, ca. $12 \times 4 \mathrm{~cm}$ (Fig. 2). On that basis, we agree with Luer (2005) in considering $P$. subulata a synonym of $P$. cardiothallis. Schlechter (1912) described Pleurothallis acutipetala from Guatemala, mostly distinguishing it by the minutely papillose-puberulent abaxial indumentum of the sepals (Fig. 1B). In 1918, he also described another large Pleurothallis from San Ramón in Costa Rica (Schlechter 1918) under the illegitimate name of $P$. costaricensis (predated by P. costaricensis Rolfe 1917), characterized by two short keels on the ventral surface of the lip, a quite uncommon feature in the group (Fig. 1C). Both traditionally included under the synonymy of $P$. cardiothallis, $P$. acutipetala and P. schlechteriana Ames (the avowed name for P. costaricensis Schltr.) would probably require a second look for their correct interpretation.

Hamer (1974) produced the first modern illustration of a specimen interpreted as $P$. cardiothallis, based

— Left, Figure 1. A, Reichenbach's sketches of the flower that served as the holotype for Pleurothallis cardiothallis (W). B, tracing of Schlechter's drawings of a syntype of Pleurothallis acutipetala (Guatemala, H. von Türckheim 860, AMES 74023). C, tracings of the original drawing of the holotype of Pleurothallis costaricensis (= P. schlechteriana), made under Schlechter's supervision, designated as the species lectotype by Pupulin et al. (2016) (AMES 23674). D, Hamer's illustration of Pleurothallis cardiothallis from Nicaragua (Icones plantarum tropicarum, t. 1086). A, reproduced with permission of the Naturhistorische Museum Wien (courtesy of Mark Wilson); B, C: reproduced with permission by the President and Fellows of Harvard College. D: courtesy of the Marie Selby Botanical Gardens. 


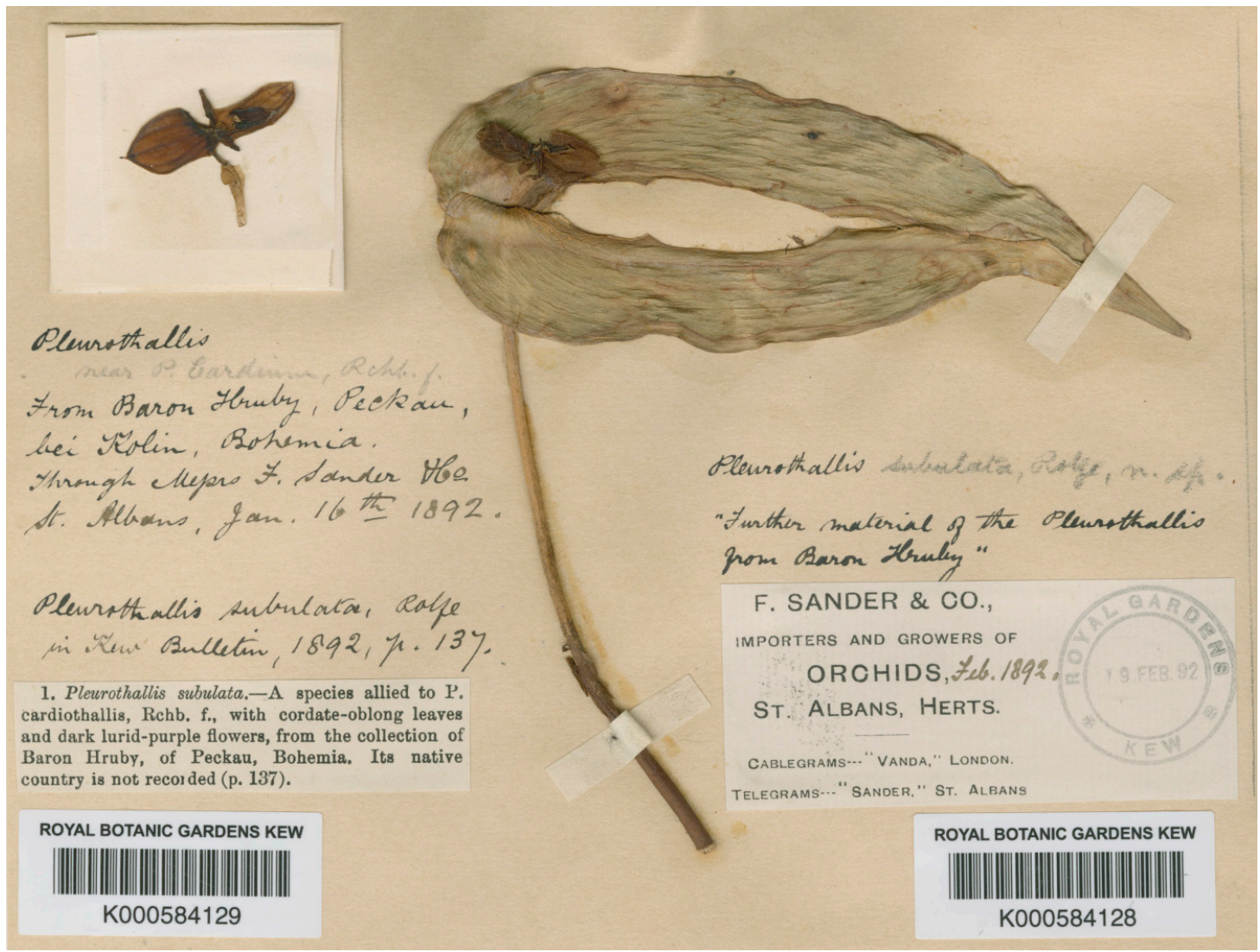

FIGURE 2. The holotype specimen of Pleurothallis subulata (left, K 584128) and another specimen prepared from the same plant at a later date (right, K 584129). Copyright of the Board of Trustees of the Royal Botanic Gardens, Kew.

on a plant from Cerro Montecristo in El Salvador, showing the characteristic peltate lip and slightly falcate petals that become permanently associated with the current use of the name. Of the several records of $P$. cardiothallis cited for Mexico, (Williams 1951, Hágsater et al. 2005), Guatemala (Ames \& Correll 1952), Belize (McLeish et al. 1995, Sayers \& Adams 2009), El Salvador (Hamer 1974), Honduras (Wiese 2015, Pérez Munguía 2015), Nicaragua (Hamer 1984, 2001), Panama (Dressler 1980, Kolanowska 2014), few are illustrated in a way that allows a clear and positive identification. The photo published by Hágsater and collaborators (2005: 56) for Mexico, by Sayers and Adams (2009: 57) for Belize, and by Pérez Munguía (2015: 196, as P. titan) surely correspond to our concept of $P$. cardiothallis, as well as the drawing prepared by Hamer (1974: 215) for El Salvador, and the photographs of the two purple and yellow morphs published by Kolanowska (2014: 326) for the Darién
Gap in Panama. These latter photos, however, were ostensibly taken in Costa Rica. The drawing of $P$. cardiothallis proposed by Hamer (1984: t. 1086) shows a distinct velutine-hirsute indumentum of the lip (Fig. 1D), which is neither present in the drawing attached to the type nor in the multiple specimens that we examined for this study. Luer (2005) discussed the taxonomy of $P$. cardiothallis in his monograph on section Macrophyllae-Fasciculatae (under Acronia Presl.), where he also produced a fine illustration of the species, based on a Panamanian collection. He opted for a broad circumscription of the taxon, whose range was extended to Colombia and Ecuador along the Andes, even though he acknowledged "some variations appear distinct".

As the systematics of most groups of tropical Orchidaceae have largely been done through the study of herbarium specimens, it is not surprising that ecological aspects of the orchid flowers, like the timing of floral 
activity, were seldom recorded. Flower longevity and periodicity influence the success of plant reproduction (Primack 1985, Stratton 1989, Martini et al. 2003, Abdala-Roberts et al. 2007, Parra-Tabla \& Vargas 2007, Srimuang et al. 2010, Santos Fonseca et al. 2015, Vega \& Marques 2015). Long flower lifespans effectively increase pollinator visitation (Internicola \& Harder 2012), and this trait has been frequently associated with deceit-pollination species, while short activity of the flowers has been interpreted as a temporal niche, aimed at reducing competition with other species that occupy the same habitat, rely on the same pollinators, and are active at different times (Santos \& Presley 2010, Aguiar et al. 2013). Physiological arguments have also been proposed to explain reduced flower longevity, based on the need to reduce transpirational water loss and metabolic costs (Primack 1985) or to protect the reproductive organs from damage through early flower closure (van Doorn \& van Meeteren, 2003). However, the specific timing of flower activity in orchids (including phenology of individuals and populations, lifespan of individual flowers and inflorescences, changes in floral arrangement, timing in the production of chemical compounds, etc.), has been in general poorly documented, as well as flowering behavior as a response to different stimuli (Kogler 2010, van Doorn \& Kamdee 2014).

Most of the observations on floral activity in the Orchidaceae are framed within pollination studies. The timing of the scent emission in different species has been studied to show a relationship between the emission of fragrances and the period of major activity of pollinators (Matile \& Altenburger 1988, Ramos Cardoso 2014, Huber et al. 2005, Pupulin 2007, Nielsen \& Møller 2015). Flower ephemerality has also been documented to explain the "gregarious flowering" syndrome of species with short-lived flowers in several unrelated groups of orchids (Went 1898, Burkill 1917, Arens 1923, Seifriz 1923, Smith 1926, Holttum 1949, van der Pijl \& Dodson 1966, Gerlach 1992a, 1992b), and Rothacker (2007) has shown that this character is quite widespread in the primitive Epidendroideae. No cases of massblooming and gregarious flowering have been recorded so far in the Pleurothallidinae, even though the life-span of individual flowers can vary quite significantly among and within genera. Individual flowers of Specklinia colombiana (Garay) Pridgeon \& W.M. Chase only last
1-2 days, while the flowers of Diodonopsis erinacea (Rchb. f.) Pridgeon \& M.W. Chase stay open for 30 days (pers. observ.), and Lepanthes escobariana Garay is reported in the literature to have individual flowers lasting up to three months (di Vita 2017). However, most genera and species in the subtribe have anthesis periods of 7-15 days (pers. observ.).

Even though the presence or absence of temporal floral activity (i.e., successive opening and closing of the flowers during anthesis) has generally not been recorded in species of Pleurothallis, it is of taxonomic significance. It is prominently featured in a small group of species characterized by large vegetative habit, allied to P. cardiothallis Rchb.f., and we have not recorded it in any other group of Pleurothallis.

Materials and methods. Plants intended for this study were collected between 2001 and 2016 in suitable areas all around Costa Rica and brought to Lankester Botanical Garden (JBL) for cultivation and documentation. Whenever possible, type and critical localities from where rare and/or unique species records were previously reported, were visited. Five specimens per morphospecies were collected at any given locality whenever possible. Field notes were taken during collections, including GPS and geographic data, elevation, ecological zones and main types of vegetation. Phenological data were recorded at JBL. Each plant in this group was documented at flowering by at least a high-resolution image of the flower provided with a scale, and more generally of the whole plant and floral details with relative scales. To document floral behavior, flowers were photographed at intervals of two hours, from 7:30AM to 4:30PM during the entire period of anthesis. Photographs were taken with Nikon cameras (D5200, D7100, D810) fitted with macro lenses (Micro Nikkor 60mm f/2.8, Micro Nikkor $105 \mathrm{~mm}$ AF f/2.8, Micro Nikkor 105mm G AF-S/ED-IF/VR f/2.8, Sigma Macro 105mm AF/EX/DG/OS/HSMS f/2.8). Floral details were captured with a Micro-Nikkor $60 \mathrm{~mm}$ f.2.8 mounted on a Nikon PB6 bellow or on extension tubes, and/or with microscopes (Leica macroscope Z16APO and Leica dissecting stereo microscopes MZ9.5 and M60) fitted with Leica DFC420 Digital Color Microscope cameras. Comparative plates of flowers and/or relevant floral details were prepared with Adobe ${ }^{\circledR}$ Photoshop 5.0 and 6.0. Drawings of flowers

LANKESTERIANA 17(2). 2017. (C) Universidad de Costa Rica, 2017. 

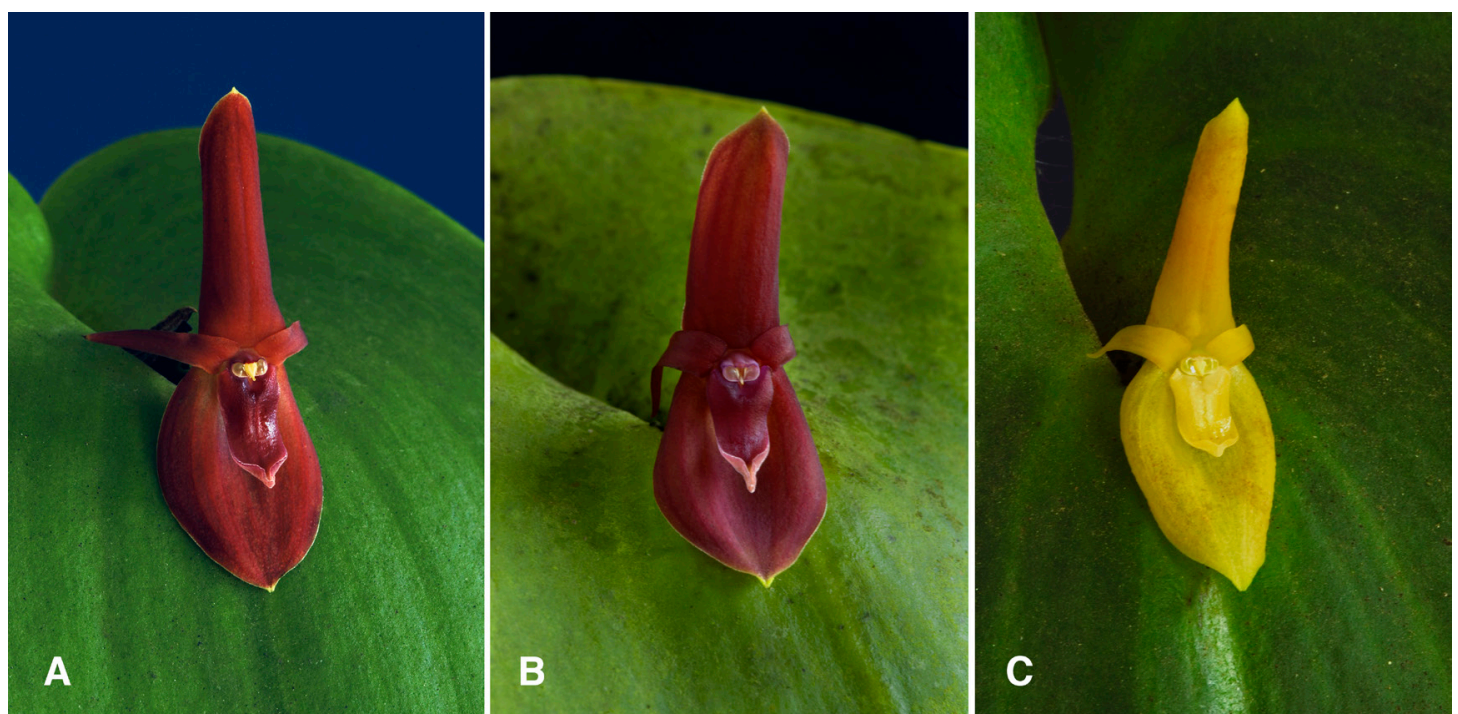

FIGURE 3. Flowers of Pleurothallis cardiothallis at full anthesis, showing reflexed sepals and petals. A, Blanco 1863 (JBL).

B, Dressler 6762 (JBL). C, Pupulin 6414 (JBL). Photographs by F. Pupulin.

and floral details were prepared using dissecting stereo microscopes Leica MZ9.5 and M60, fitted with Leica ApoPlanar lenses and with drawing tubes. Vouchers for each specimen were conserved in the liquid collection of JBL. Individual plants intended for the description of new species were also preserved as dried specimens to be deposited in national herbaria. Measurements were mostly taken under a dissecting stereoscope, or with the aid of the electronic scale bars inserted in the high definition images of the floral details. The major herbaria of the country, as well as relevant herbaria that allow digital access to their collections, were revised to study specimens of the taxa intended for this study, and specimens annotated when required. Over 60 individuals, belonging to at least six morphospecies (Pupulin et al., in prep.), within this group were documented morphologically. Notes on floral ecology were taken through direct observation of the plants under the semi-artificial conditions of open greenhouses. The aging of individual flowers was documented with the same techniques and equipment used for general flower documentation.

Results. The $P$. cardiothallis Rchb.f. group, as treated in this study, includes large plants (taller than $20 \mathrm{~cm}$ ) with ovate to lanceolate, soft-coriaceous, elastic, leaves, deeply cordate at the base when mature (immature leaves maybe cuneate), the basal margins frequently overlapping, without a distinctly protruding mid-vein, matte on upper surface, usually less than 4 times longer than broad; the spathaceous bract always prostrate; the flowers membranaceous, with the sepals and petals thin and almost translucent, with distinct temporal activity, opening and closing several times during anthesis. Several other assemblages of species share one or more of these characters, but all together, as a specific set of features, they sharply define a discrete and recognizable group of taxa. No scent perceivable by the human nose was detected.

Taxonomically informative characters include the size of the plants, the size and color of the flowers, the absolute and relative size of the perianth parts, the shape of the flowers at maturity, as well as the size, shape, orientation, indumentum, and venation of the sepals, petals and lip.

In P. cardiothallis, the extension of the sepals and petals continues until the lateral margins of the sepals and the apex of the petals are completely reflexed (Fig. 3). As environmental humidity decreases, during the late hours of the morning and at noon, the tip of the petals begin curving towards the column, while the dorsal sepal and synsepal progressively approach each other until the perianth completely close (Fig. 4). During rainy days, the flowers remain active for longer times, and on several occasions, the closure of the flower is not complete. 


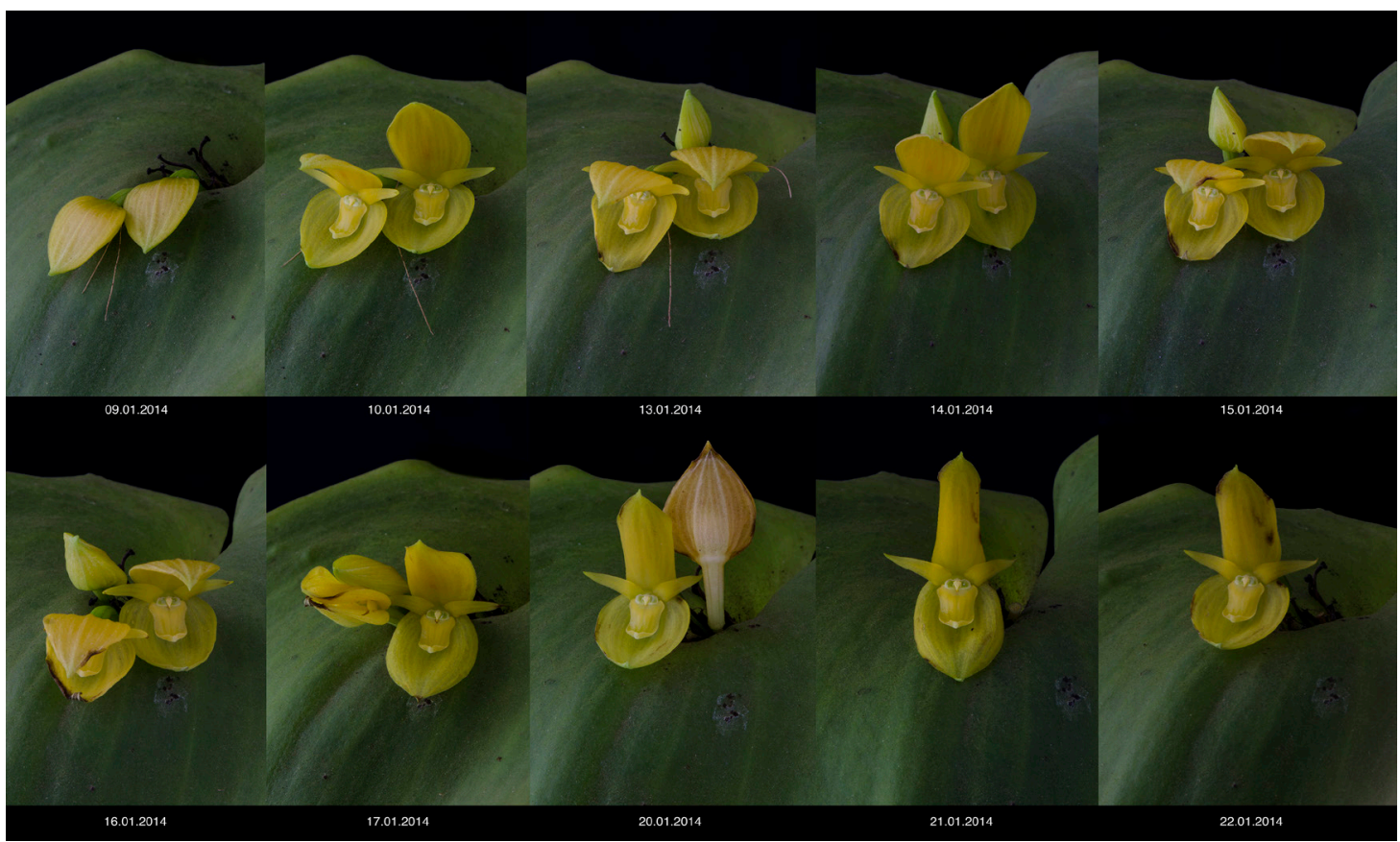

FIGURE 4. Temporal activity on flower of Pleurothallis cardiothallis. Flower in the foreground is at the third day of anthesis on 09.01; it partially opens and closes during the next six days, until it fades on 18.01. Flower on the background begins anthesis on 10.01, it opens and closes during the next ten days, until it fades on 20.01. A new floral bud is partially developed on 13.01; it begins anthesis on 20.01, and reaches its fully spread shape on 21.01, then partially closes on 22.01. All the photographs taken approximately at 9:00AM. Voucher: F. Pupulin 6414 (JBL). Photographs by J. Aguilar.

Discussion. When specimens vegetatively similar to $P$. cardiothallis are sorted by distinctive features, it becomes apparent that several different species, in need of formal recognition, have been hidden under this name. In this paper we conservatively interpret as $P$. cardiothallis populations of Costa Rican Pleurothallis species that closely resemble the illustration of the type. We agree here with the currently accepted concept of $P$. cardiothallis, as exemplified by Luer's (2005) illustration, and we interpret Reichenbach's drawings of the type as depicting a flower not completely spread, before it reached the typical reflexed shape that can be observed on fully mature flowers (Fig. 5A).

As a group, the species close to $P$. cardiothallis are distinctive as they exhibit a characteristic temporal activity of the flowers. During the anthesis period, the flowers usually spread out in the early morning, and the sepals attain an almost flat or slightly concave condition (Fig. 3), however they close up daily during the late hours of the morning and at noon (Fig. 4). During rainy days, the flowers remain active for longer times, and on several occasions, the closure of the flower is not complete. Environmental humidity has a direct effect on flower turgor and is likely to be a main factor in the temporal activity of these flowers. Induced opening of partially or completely closed flowers was achieved by exposing plants to the rain or an artificial fog-system. The flowers completely reopen approximately one hour after exposure.

Temporal activity of the flowers has been rarely recorded, and this is not surprising considering that, in general terms, the published studies on other aspects of the biology of the Pleurothallidinae are uncommon and unevenly distributed among the genera when compared to the number of papers dealing with the diversity, phylogenetics, and classification of this group of plants. The information on the anatomy, palynology, and cytogenetics of the Pleurothallidinae is scarce relatively to the size of the subtribe (summarized in Pridgeon 2005), and even scantier are the studies on its reproductive biology (Chase 1985, Christensen 1992, 1994, Singer \& Cocucci 1999, Borba \& Semir 2001, Borba et al. 2001, Blanco \& Barbosa 2005, AlboresOrtiz \& Sosa 2006, de Melo 2008, Barbosa et al. 2009, 


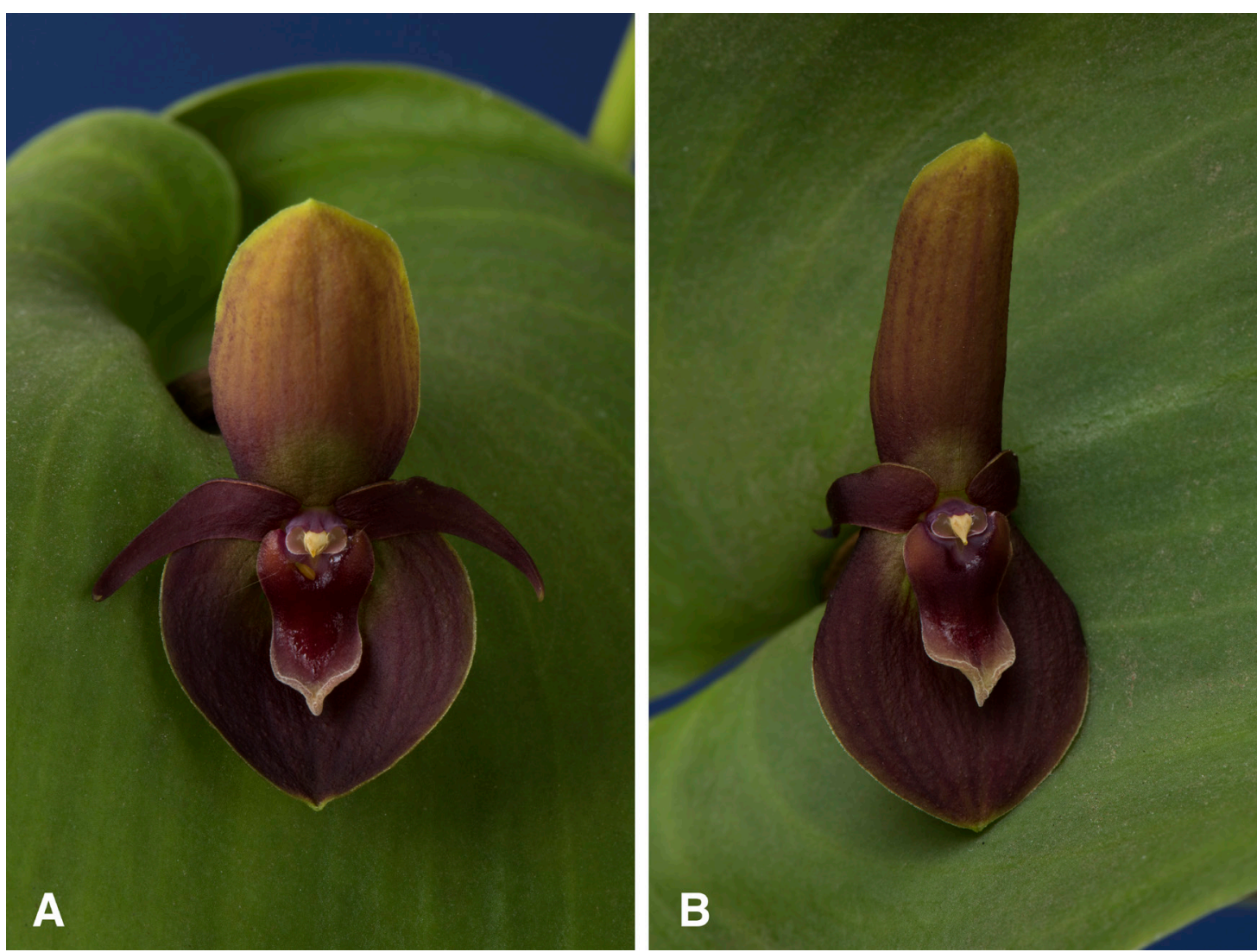

Figure 5. Flower of Pleurothallis cardiothallis during the first stage of anthesis (A) and fully expanded (B). Based on Karremans 6580 (JBL).

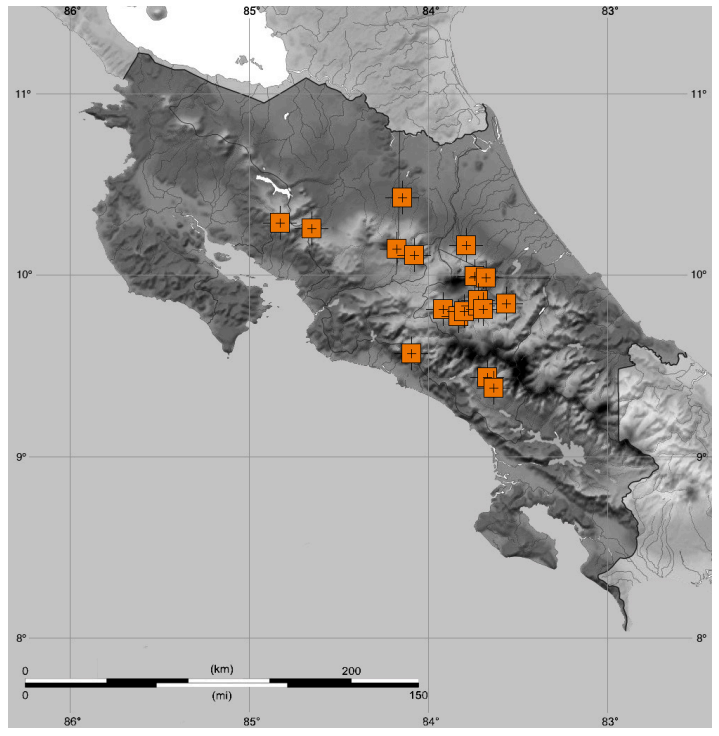

FIGURE 6. Distribution map of Pleurothallis cardiothallis in Costa Rica.
CaraDonna \& Ackerman 2010, de Melo et al. 2010, Endara et al. 2010, Borba et al. 2011, Pupulin et al. 2012, Duque Buitrago et al. 2013, Karremans et al. 2016, Pansarín et al. 2016), which somehow associate the mutual behavior of flowers and their pollinators.

In Costa Rica, we documented some 30 specimens we interpret as $P$. cardiothallis from different localities on both watersheds of the Talamanca, Central Volcanic, and Tilarán mountain ranges (Fig. 6). We also documented a number of other populations, which do not agree with the type of $P$. cardiothallis in plant and flower morphology, and which seemingly represent a complex of related species that is not reflected in the currently accepted nomenclature. Together with $P$. cardiothallis, the only other name that received a general consensus to describe the diversity of the group in Costa Rica is $P$. oncoglossa Luer, distinguished from $P$. cardiothallis by its large, triangular lip with a narrow, hook-like apex (Luer 1996) (Fig. 7). Hereafter 


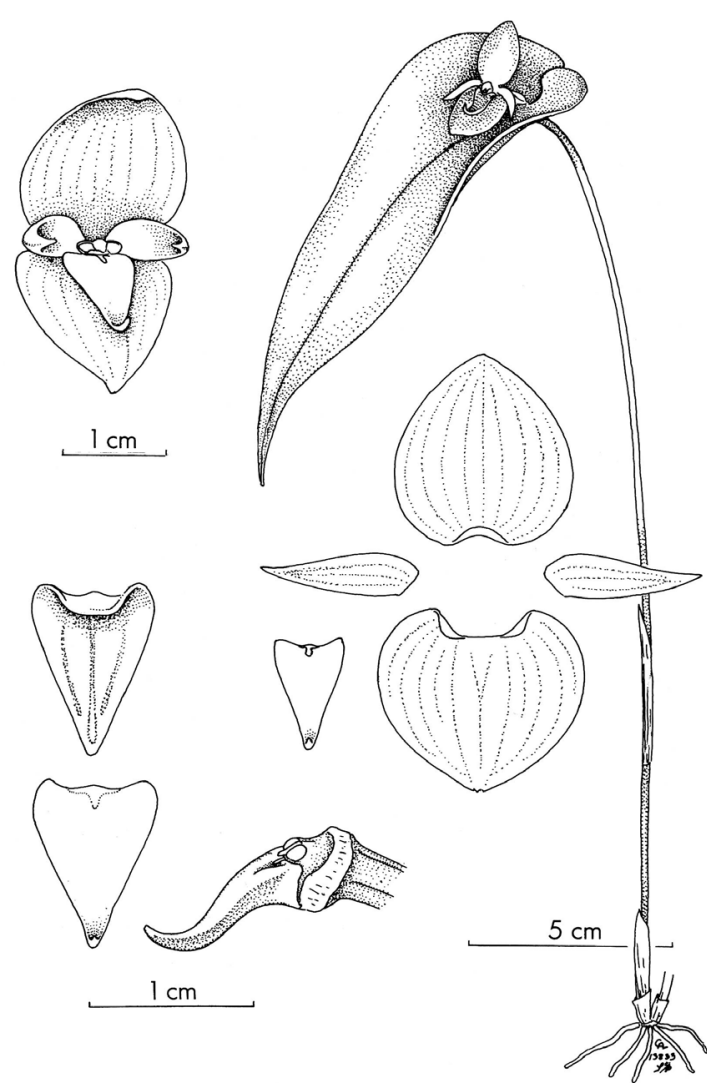

FiguRE 7. Pleurothallis oncoglossa. Luer's illustration of the holotype (Luer 13833, MO). Courtesy of the American Orchid Society.

we describe two other species in this group, they are closely related to $P$. cardiothallis and $P$. oncoglossa respectively.

\section{TAXONOMIC TREATMENT}

Pleurothallis scotinantha Pupulin, M.Díaz \& J.Aguilar, sp. nov.

TYPE: Costa Rica. San José: Pérez Zeledón, Cajón, Montecarlo, $3.5 \mathrm{~km}$ al noreste de Montecarlo, orillas del Río Peña Blanquita, 9॰22’20.3” N 83³5'01.8” $\mathrm{W}, 1261 \mathrm{~m}$, bosque pluvial premontano, en bosque secundario remanente a orillas del río, 28 Julio 2009, D. Bogarin 7355 \& F. Pupulin (holotype, JBL; isotype, JBL) (Fig. 8-10, 11A, 14A, 15A).

Species Pleurothallidi oncoglossa Luer similis, floribus concoloribus atrovinaceis, petalis distincte deflexis, labelli apice extendido ecalloso recedit.
Plant an epiphytic, caespitose, erect to suberect, large herb to $50 \mathrm{~cm}$ tall. Roots slender, flexuous, ca. $1.5 \mathrm{~mm}$ in diameter. Ramicauls terete, slender, 29.0 $43.5 \mathrm{~cm}$ long, $2.5-4.0 \mathrm{~mm}$ in diameter, yellowish green, provided with a tubular, short, truncate sheath to $3.5-4.0 \mathrm{~cm}$ long at the base, and a longer, tubular, tightly adpressed, truncate sheath below the middle, to 4-6 cm long, the bracts glumaceous, pale green when young, becoming brown, dry-papyraceous with age. Leaf borne horizontally at the apex of the ramicaul, becoming subpendent with age, thinly coriaceous, flexible, sessile, ovate, acute to acuminate, $16-19 \times 7.5-8.0 \mathrm{~cm}$, deeply cordate, forming two slightly imbricate lobes at the base, grass green, matte. Inflorescence a solitary flower, usually produced singly, rarely in pairs, from a reclined spathaceous bract 10-15 mm long, brown, dry-papyraceous when mature, eventually dissolving with age. Pedicel terete, pale green, 22-26 mm long. Ovary clavate, rounded in section, 4-8 mm long. Flowers solid dark purple with pale yellow tips on sepals, petals and lip, with temporal activity, short-lived (usually 5 , rarely to 6 days). Dorsal sepal broadly ovate, subacute, 14-18 $\times$ 11-19 mm, 9-11 veined. Lateral sepals connate into a broadly ovate-subrounded, subacute synsepal, 11-20 $\times 15-20 \mathrm{~mm}, 9-11$ veined. Petals subfalcate, acute, $11-14 \times 2.5-3.5 \mathrm{~mm}, 3-5$ veined. Lip unguiculate, hinged to the column foot, triangular, basally truncate with rounded angles, acuminate, 6-7 $\times$ $4.0-4.5 \mathrm{~mm}$, strongly conduplicate at the base, apex with the margin finely pubescent; glenion deeply recessed between the basal lobes of the lip, ca. 1.2 $\mathrm{mm}$ long. Column short, transversely subrectangular, dorsiventrally complanate, ca. $1.3 \times 4.0 \mathrm{~mm}$, the anther apical, bent, the stigma apical, bilobed. Anther cap obtriangular, acute, bilobed at the base, 2-celled, ca. $1.8 \times 1.2 \mathrm{~mm}$. Pollinia two, narrowly oblongpyriform, $2 \mathrm{~mm}$ long, attached to an elliptic viscidium through a short, cylindric caudicle. Fruit not seen.

Paratype: Costa Rica. Alajuela: Carrizal, Concordia, between Los Cartagos and Cinco Esquinas, $10^{\circ} 08^{\prime} 16.8^{\prime \prime} \mathrm{N} 84^{\circ} 09^{\prime} 49.8^{\prime} \mathrm{W}, 2027 \mathrm{~m}$, lower montane rain forest, in pastures with trees and secondary forest, 17 June 2009, flowered in cultivation at Jardín Botánico Lankester, 8 Jan. 2010, D. Bogarín 7455, R.L. Dressler, F. Pupulin \& R. Trejos (JBL) (Fig. 11B, 12, 14B, 15B). 


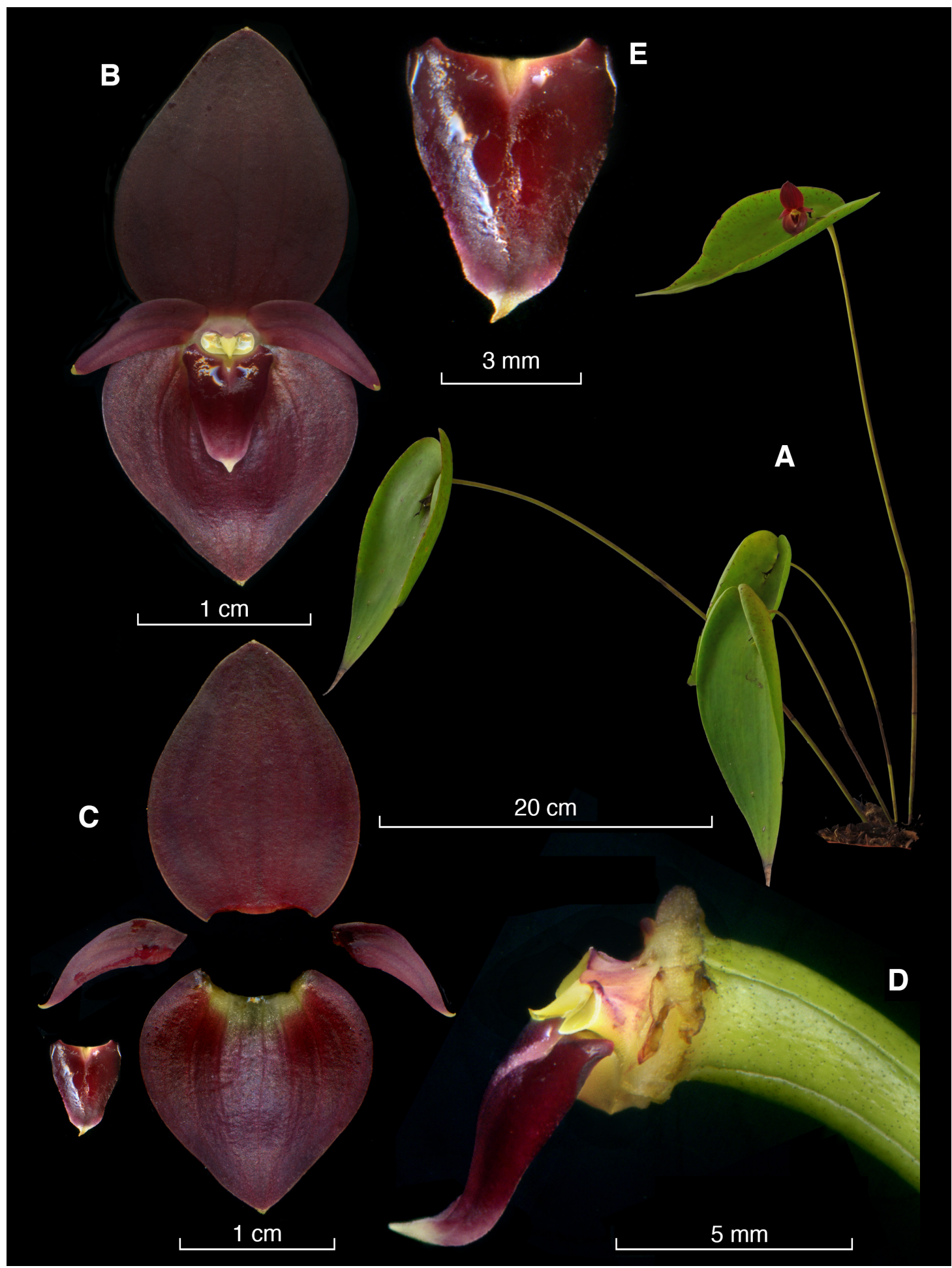

Figure 8. Pleurothallis scotinantha. Lankester Composite Digital Plate based on the plant that served as the holotype. A, habit. B, flower. C, dissected perianth. D, column and lip, lateral view. E, lip, ventral view. Prepared by F. Pupulin. 


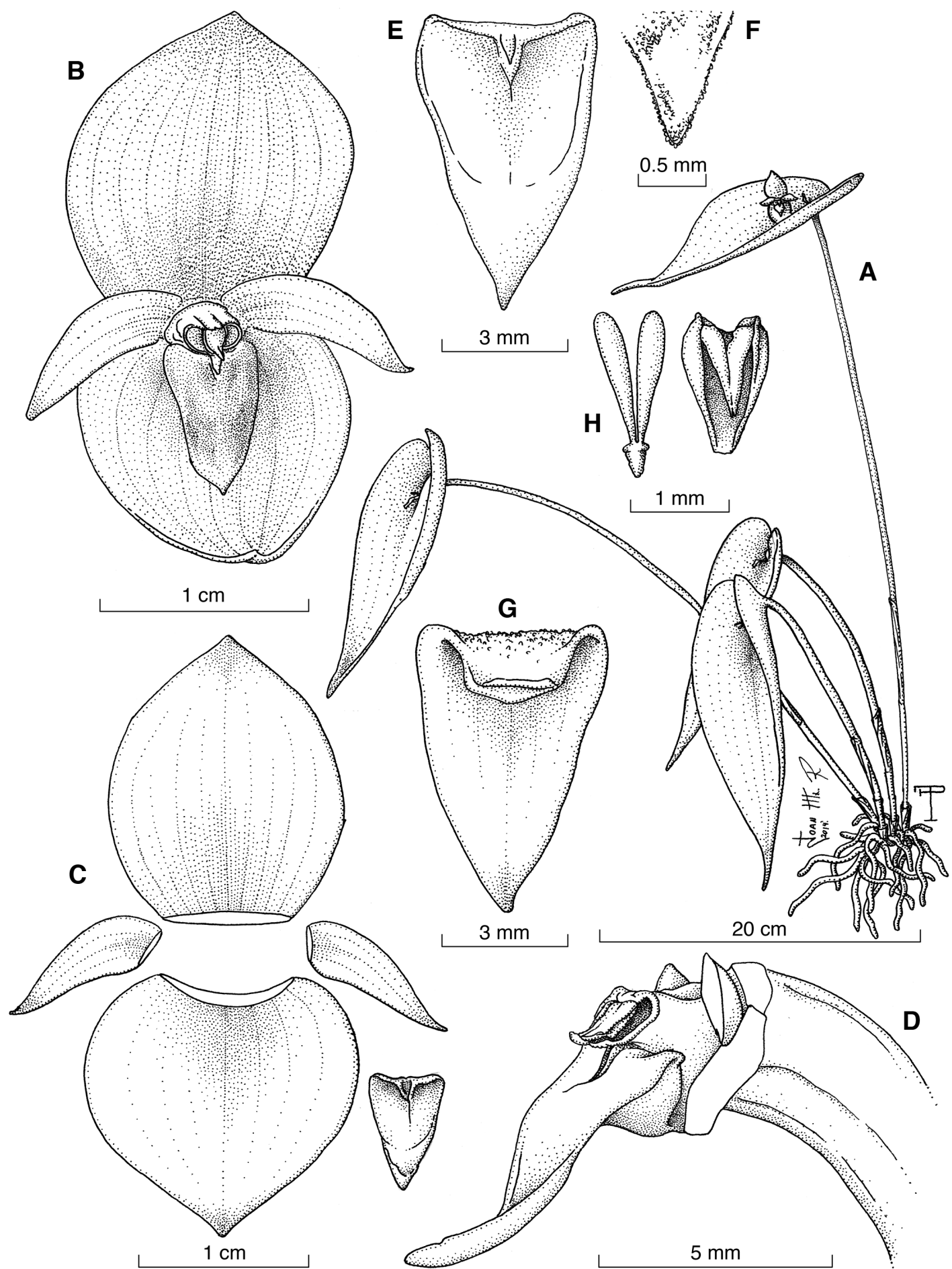

Figure 9. Pleurothallis scotinantha Pupulin, M.Díaz \& J.Aguilar. A, habit. B, flower. C, dissected perianth. D, column and lip, lateral view. E, lip, adaxial view. F, apex of lip. G, lip, abaxial view. H, pollinarium and anther cap. Drawing by Darha Solano Ulate and F. Pupulin based on the plant that served as the holotype. 


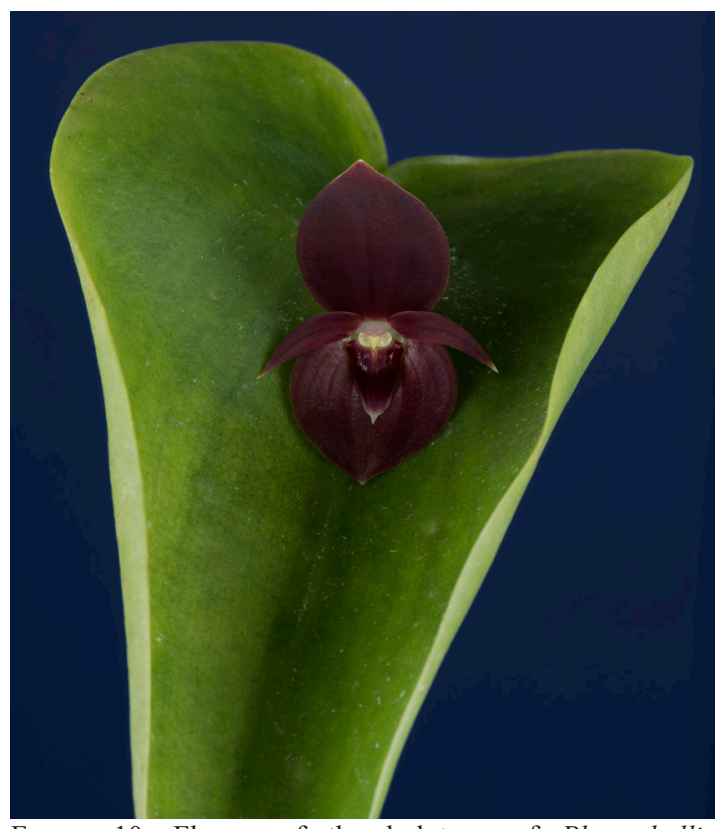

FIGURE 10. Flower of the holotype of Pleurothallis scotinantha. Photograph by F. Pupulin.

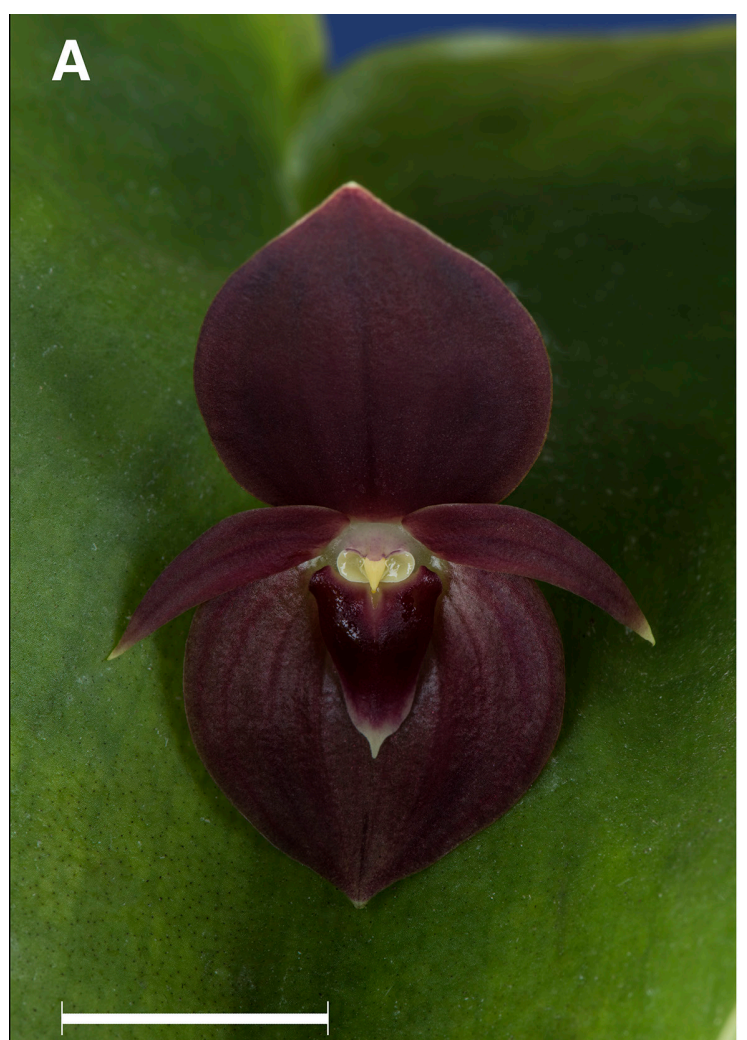

Figure 11. Flowers of Pleurothallis scotinantha. A, Bogarín 7355. B, Bogarín 7455. Vouchers at JBL. Scale bar $=1 \mathrm{~cm}$. Photographs by F. Pupulin.

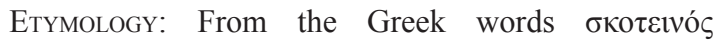

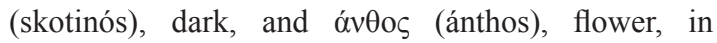
reference to the solid, dark purple flower of the species, uncommon in this group.

Distribution: Known from the Cordillera Central and Cordillera de Talamanca in Costa Rica, at 1200-2000 m elevation (Fig. 13).

HaBitAT AND ECOLOGY: An epiphyte of wet premontane and lower montane forest, at mid-elevations on the Pacific watershed of both the Cordillera Central and Cordillera de Talamanca, $P$. scotinantha is associated with forest remnants close to river banks, forest edges or isolated trees in pastures. Flowering, both in the field and in cultivation, has been recorded from May to July, and November to January.

Lacking univocal information about the origin of $P$. cardiothallis, the view that the distribution of the species spans from southern Mexico, over the entire CentralAmerican isthmus, to the northern portion of the

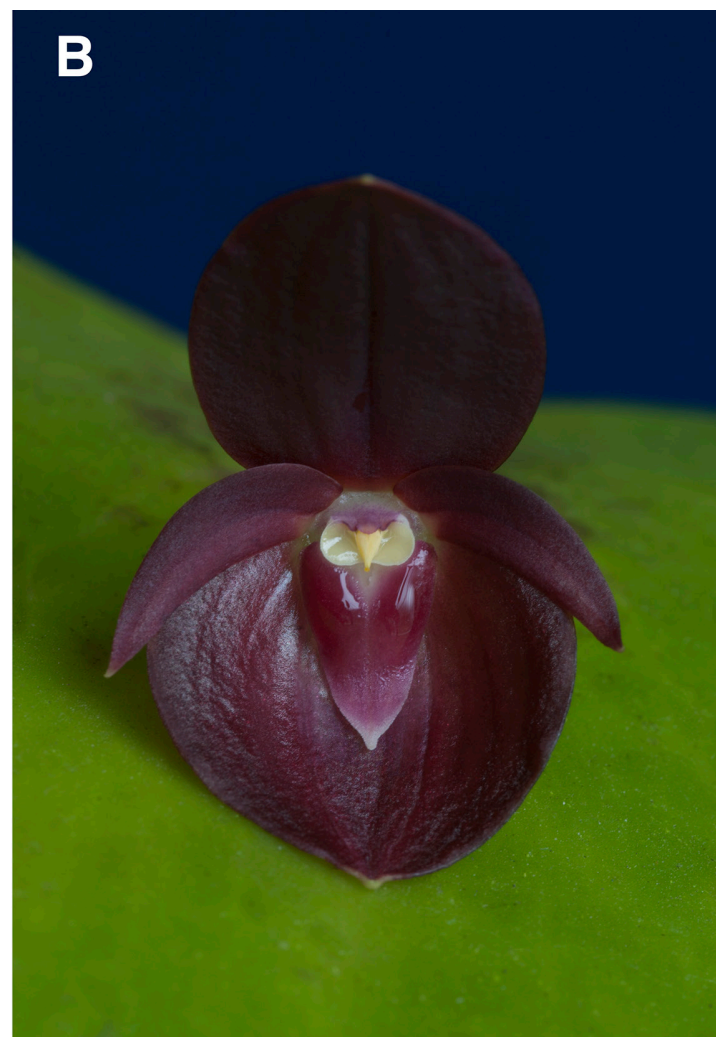

LANKESTERIANA 17(2). 2017. (C) Universidad de Costa Rica, 2017. 

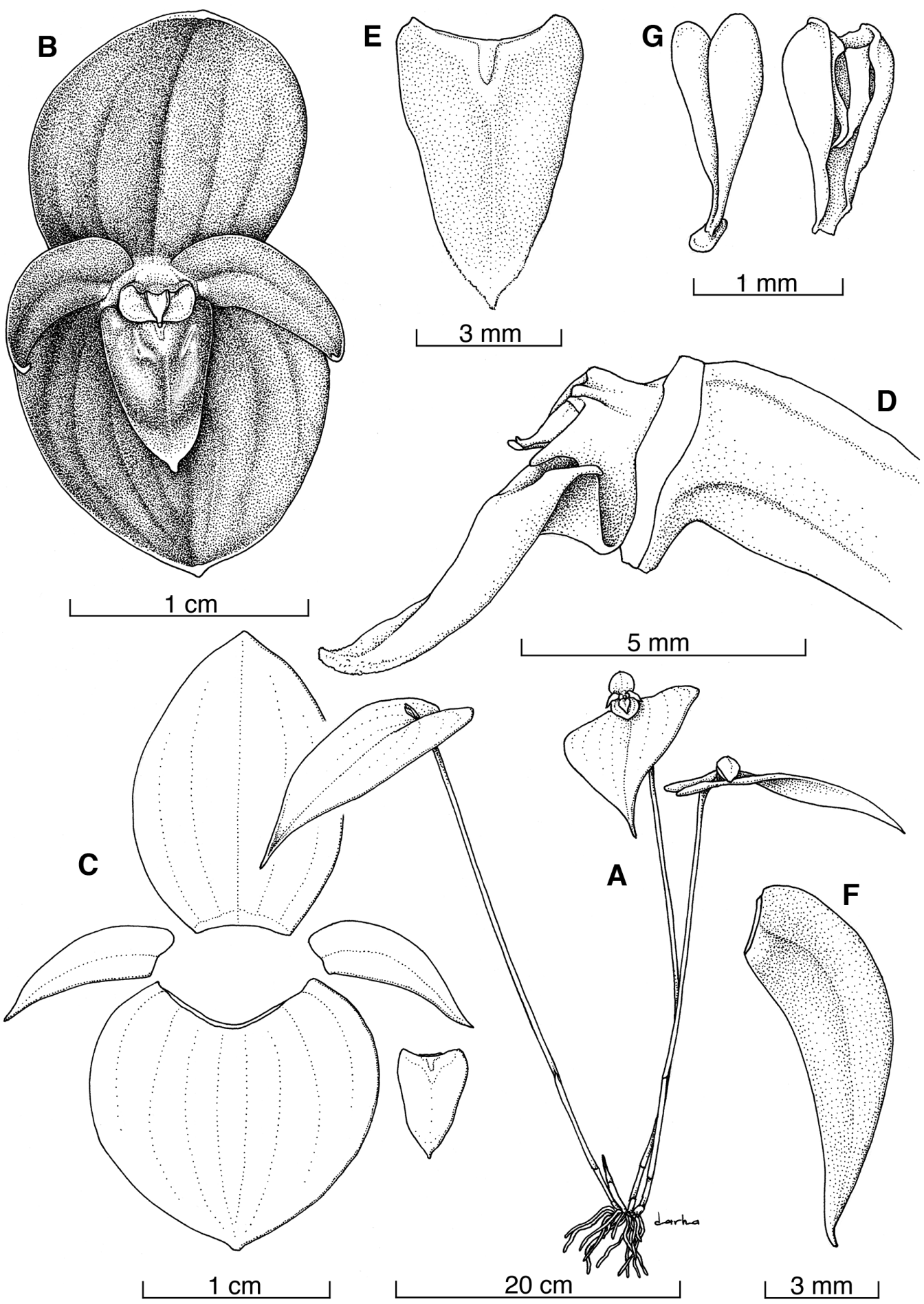

FIGURE 12. Pleurothallis scotinantha. A, habit. B, flower. C, dissected perianth. D, column and lip, lateral view. E, lip, ventral view. F, petal. G, pollinarium and anther cap. Drawn by Darha Solano Ulate and F. Pupulin based on D. Bogarín 7455 (JBL). 


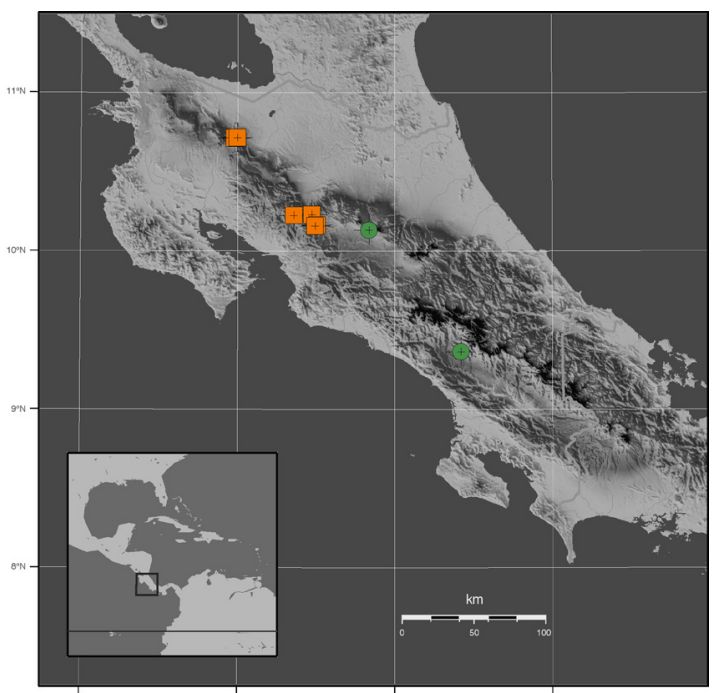

FIGURE 13. Distribution map of $P$. scotinantha (green circles) and $P$. navisepala (orange squares) in Costa Rica.
Andes in South America, has prevailed in taxonomic literature. Inevitably, this interpretation lead to a concept of $P$. cardiothallis as a "variable species", reducing under this name most of the observed morphological variation in large Pleurothallis plants of the Macrophyllae-Fasciculatae group. This is not, however, what we find in Costa Rican populations, which present discrete and recognizable variations throughout the sampled individuals. Whilst the lip of $P$. cardiothallis is unequivocally shield-shaped in outline, the lip of $P$. scotinantha is triangular, more similar in general shape to that of $P$. oncoglossa. As well as in $P$. oncoglossa, the flower is fully spread at the peak of anthesis, and the sepals do not reflex backwards as in P. cardiothallis. The dark purple, blackish, glossy color of the flower, the triangular, flat, dark purple lip fading into a small white region towards the apex, whitish on the underside, are useful

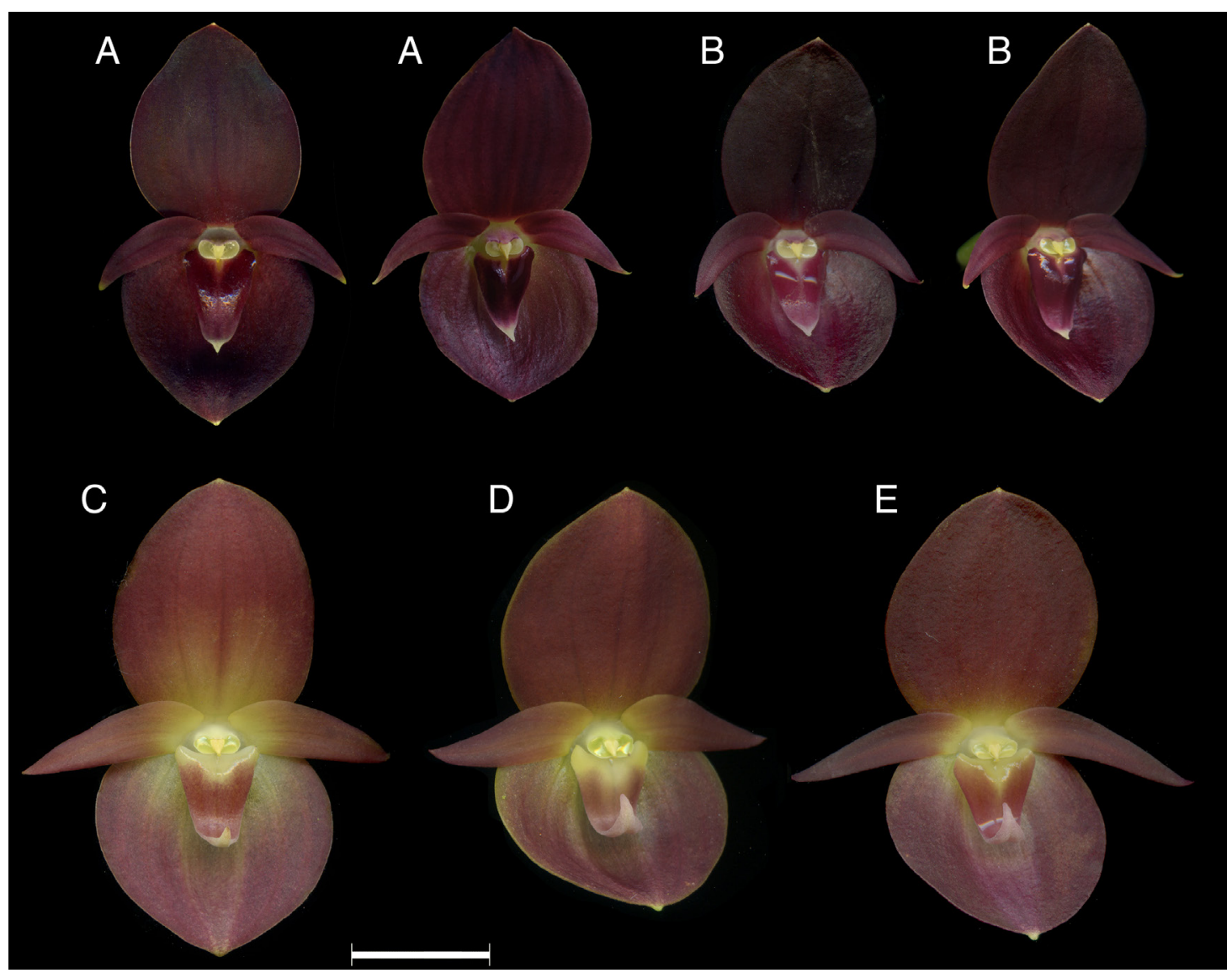

Figure 14. Comparison between the flowers of Pleurothallis scotinantha (A-B) and P. oncoglossa (C-E). A, Bogarin 7355 . B, Bogarín 7455. C, Bogarín 5686. D, Bogarín 3843. E, Fernández 110. Scale bar $=1 \mathrm{~cm}$. All the vouchers at JBL. 


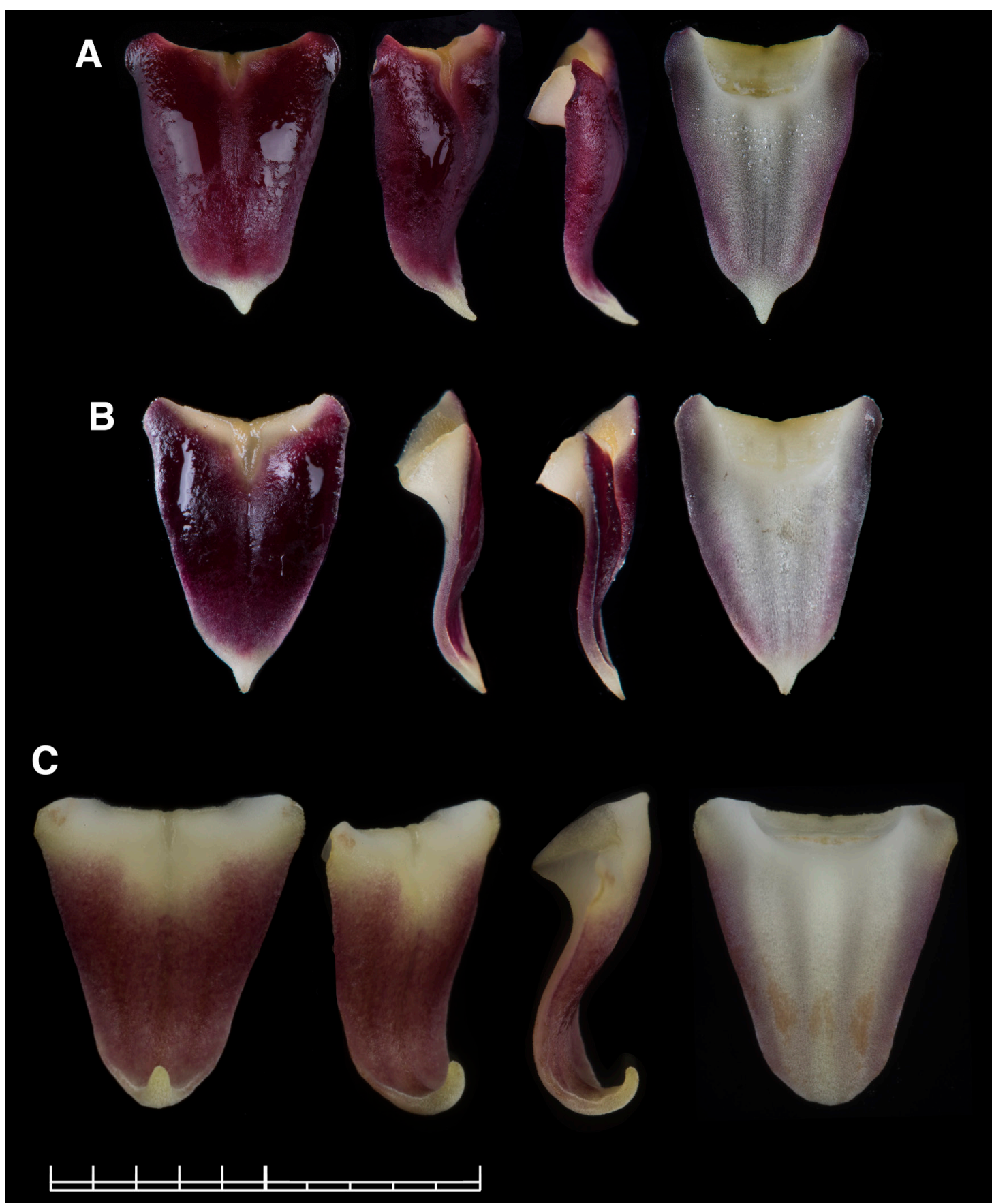

FIGURE 15. Comparison between the lips of Pleurothallis scotinantha (A-B) and P. oncoglossa (C) in adaxial, three quarters, lateral, and abaxial views. A, Bogarín 7355. B, Bogarín 7455. C, Bogarín 5686. Scale bar $=1 \mathrm{~cm}$. All the vouchers at JBL. Photographs by F. Pupulin.

characters to distinguish it from its closest relative, $P$. oncoglossa, which has light purple-red flowers on a greenish yellow background, the sepals fading yellow-green toward the base, and a characteris-tic, callose hook at the apex of the lip (Fig. 14C-E, 15C).

We have documented and illustrated two different LANKESTERIANA 17(2). 2017. (C) Universidad de Costa Rica, 2017. 


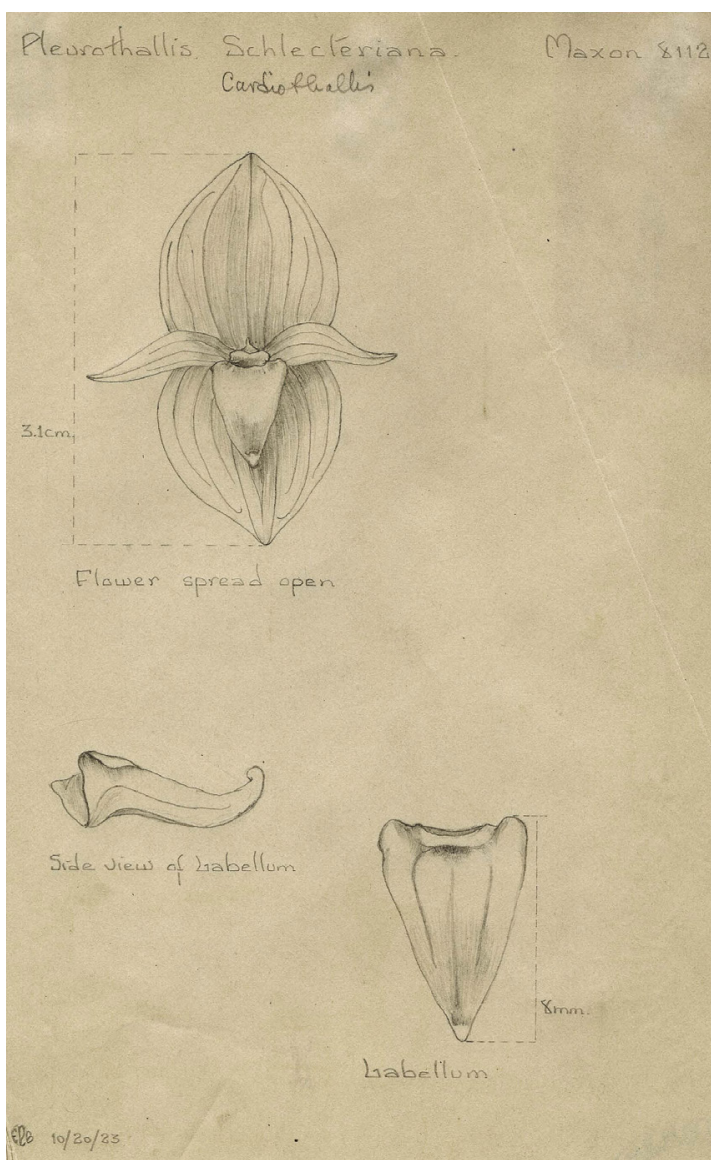

FIgURE 16. Drawing of "Pleurothallis schlechteriana", based on a Costa Rican specimen (W. R. Maxon 8112, US), kept at AMES (23615). Reproduced with permission by the President and Fellows of Harvard College.

individuals of this species, coming from two different localities that are quite far apart from each other, both in distance and ecological characteristics. Pleurothallis scotinantha is probably more common and widespread than the scanty records suggest. Dried specimens can be confused with those of other taxa of the same group. Living flowers are, however, unmistakable.

A specimen collected by W. R. Maxon and A. D. Harvey in July 1923 in the vicinities of San José, Costa Rica (no. 8112, US 1180055; AMES 23615 , drawing!), could belong to the same species, according to the illustration of the flower conserved at AMES, which shows a large flower distinctly triangular lip and relatively broad, slightly downfacing petals (Fig. 16).
Pleurothallis navisepala Pupulin, J.Aguilar \& M.Díaz, sp. nov.

TYPE: Costa Rica. Alajuela: San Ramón, Ángeles, Balsa, road between San Ramón and La Fortuna de San Carlos, 10¹0'03.6”N 84²9'35.7'W, 1150 $\mathrm{m}$, epiphytic on trees in pastures close to Río Balsa, premontane rain forest, 29 May 2013, F. Pupulin 8435, D. Bogarín, M. Díaz, \& M. Fernández (holotype, JBL) (Fig. 17-19, 20A).

Species Pleurothallidi cardiothallidi Rchb.f. similis sed floribus distincte minoribus, synsepalo profunde naviculare basaliter saccato, proportione inter labellum et synsepalum multo mayore recedit.

Plant an epiphytic, caespitose, erect to suberect, large herb to $25 \mathrm{~cm}$ tall. Roots slender, flexuous, ca. $1 \mathrm{~mm}$ in diameter. Ramicauls terete, slender, 15-23 $\mathrm{cm}$ long, $0.2-0.3 \mathrm{~cm}$ in diameter, yellowish green, provided with two tubular, short, obtuse sheaths to $1.5 \mathrm{~cm}$ long at the base, and a longer, tubular, tightly adpressed, subobtuse to truncate sheath below the middle, to $3.8 \mathrm{~cm}$ long, the bracts glumaceous, pale green when young, becoming brown, dry-papyraceous with age. Leaf borne horizontally at the apex of the ramicaul, becoming curved-subpendent with age, thinly coriaceous, flexible, sessile, ovate, narrowly acute to acuminate, $5.5-14.0 \times 3.0-7.5 \mathrm{~cm}$, deeply cordate at the base, grass green, matte. Inflorescence a solitary flower, usually produced singly, rarely in pairs, from a reclined spathaceous bract to $11 \mathrm{~mm}$ long, brown, dry-papyraceous when mature, eventually dissolving with age. Pedicel terete, green, 5-8 long. Ovary terete-subclavate, curved, rounded in section, 5-8 mm long. Flowers non completely spreading, with temporal activity, short-lived (to 5 days), the sepals purple, sparkingly pale reddish and microscopically pubescent-glandulous abaxially, the sysnepal with a large, basal, pale greenish yellow, hyaline blotch, the petals purple, the lip purple-magenta, or the entire flower concolorous bright yellow. Dorsal sepal erect, ovate, acute, $5.0-6.5 \times 3.5-4.0 \mathrm{~mm}$, the margins microscopically glandulose, 7-9 veined. Lateral sepals connate into a broadly ovate, obtuse, deeply cymbiform synsepal, the margins microscopically glandulose, $5.5-6.0 \times 6.5-7.5 \mathrm{~mm}$ when spread, 9-11 veined. Petals narrowly triangular-subfalcate, subsygmoid, acuminate, $4.0-4.5 \times 1.2-1.4 \mathrm{~mm}$, 


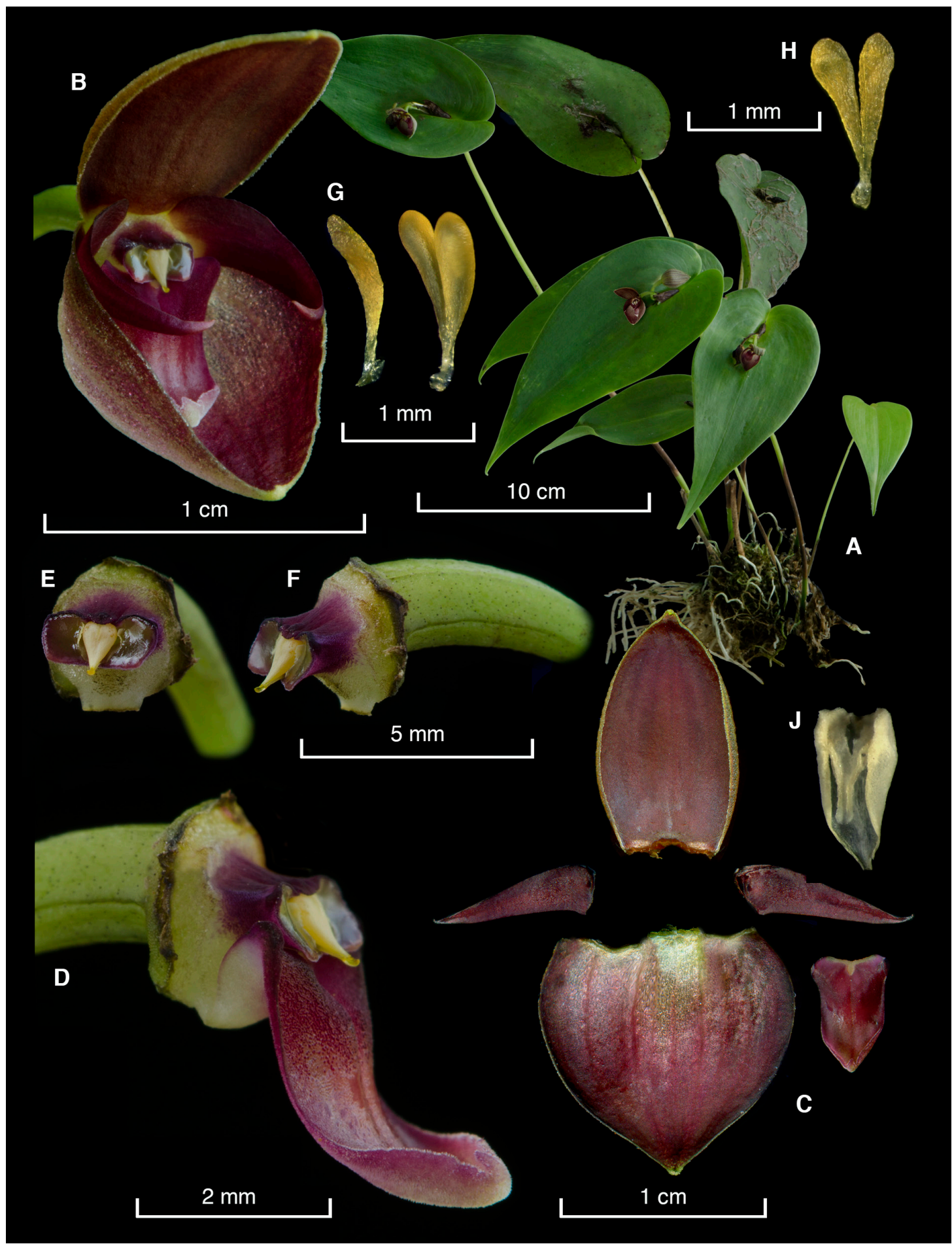

Figure 17. Pleurothallis navisepala. Lankester Composite Digital Plate based on the plant that served as the holotype. A, habit. B, flower. C, dissected perianth. D, column and lip, lateral view. E, column, frontal view, F, column, lateral view. G, pollinarium, lateral and three quarters views. H, pollinarium, ventral view. J, anther cap. Prepared by F. Pupulin. 

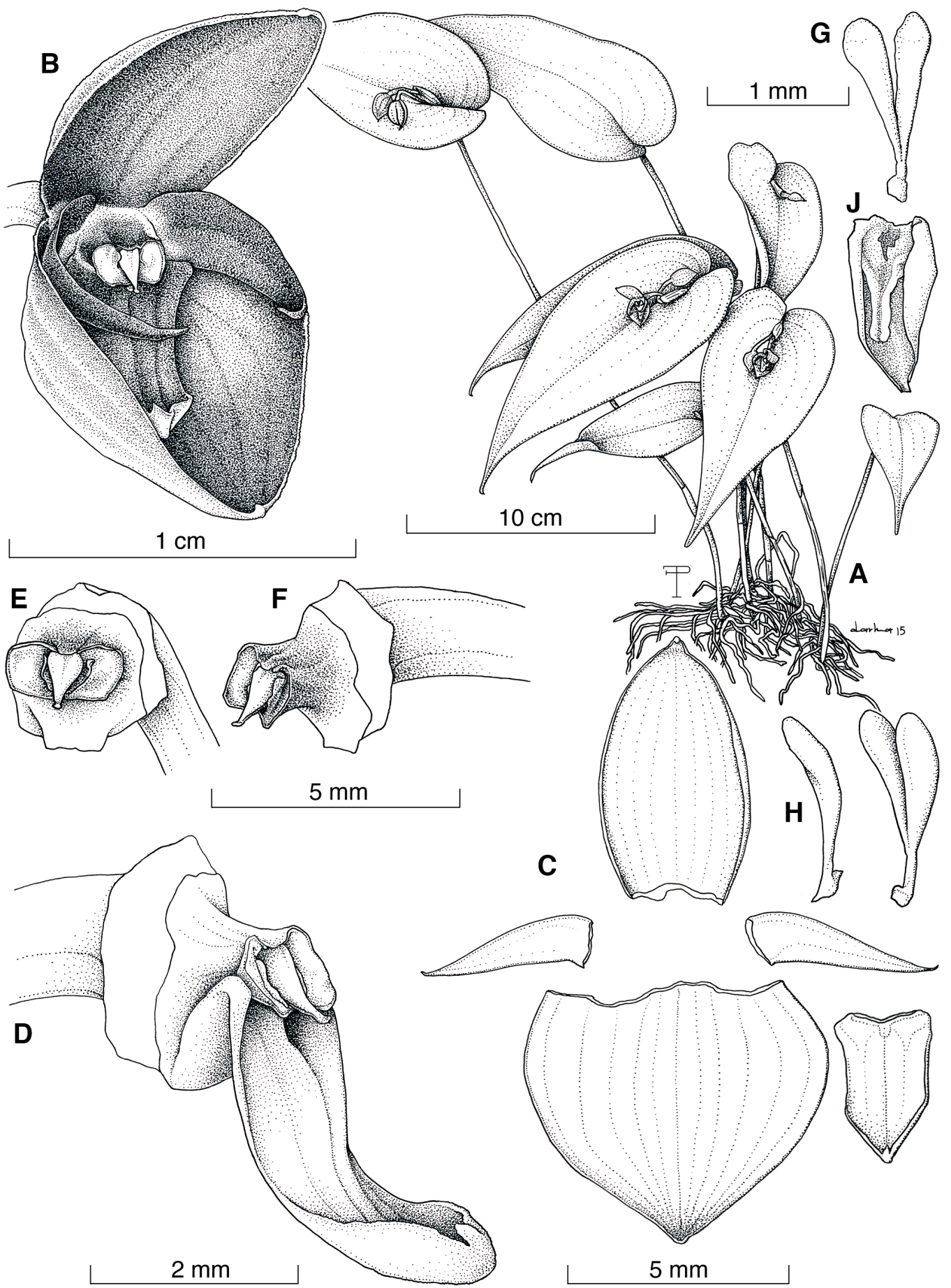
correct, apically incurved,3-veined. Lip unguiculate, hinged to the column foot, strongly geniculate, peltate, basally truncate with rounded angles, acute, apiculate, infolded, 5-8 × 3.5-5.0 mm, strongly con duplicate at the base, the apical margins thickened, inrolled, finely pubescent abaxially; glenion recessed between the thickened basal lobes of the lip, ca. 0.8 $\mathrm{mm}$ long, the front of the glenion with a line of short papillae extending to the margins of the lip. Column short, transversely subrectangular, dorsiventrally complanate, ca. $1.0 \times 2.5 \mathrm{~mm}$, the anther apical, bent, the stigma apical, bilobed. Anther cap oblong, acute, bilobed at the base, 2-celled, ca. $1.0 \times 0.5 \mathrm{~mm}$. Pollinia 2, narrowly oblong-pyriform, $1 \mathrm{~mm}$ long, attached to an elliptic viscidium through a short, cylindric caudicle. Fruit not seen.

OTHER SPECIMENS STUdied: Costa Rica. [Alajuela: San Ramón, Ángeles], Legua, Endres Pleurothallis no. 52, A. R. Endrés s.n. (W 0020259); Alajuela: San Ramón, Ángeles, Balsa, road between San Ramón and La Fortuna de San Carlos, $10^{\circ} 10^{\prime} 03.6^{\prime \prime} \mathrm{N} 8^{\circ} 29^{\prime} 35.7^{\prime \prime} \mathrm{W}$, $1150 \mathrm{~m}$, epiphytic on trees in pastures close to Río Balsa, premontane rain forest, 29 May 2013, F. Pupulin 8436, D. Bogarín, M. Díaz, \& M. Fernández (JBL); same locality and date, flowered in cultivation at Jardín Botánico Lankester, 23 Oct. 2014, F. Pupulin 8434, D. Bogarín, M. Díaz, \& M. Fernández (JBL); Alajuela:

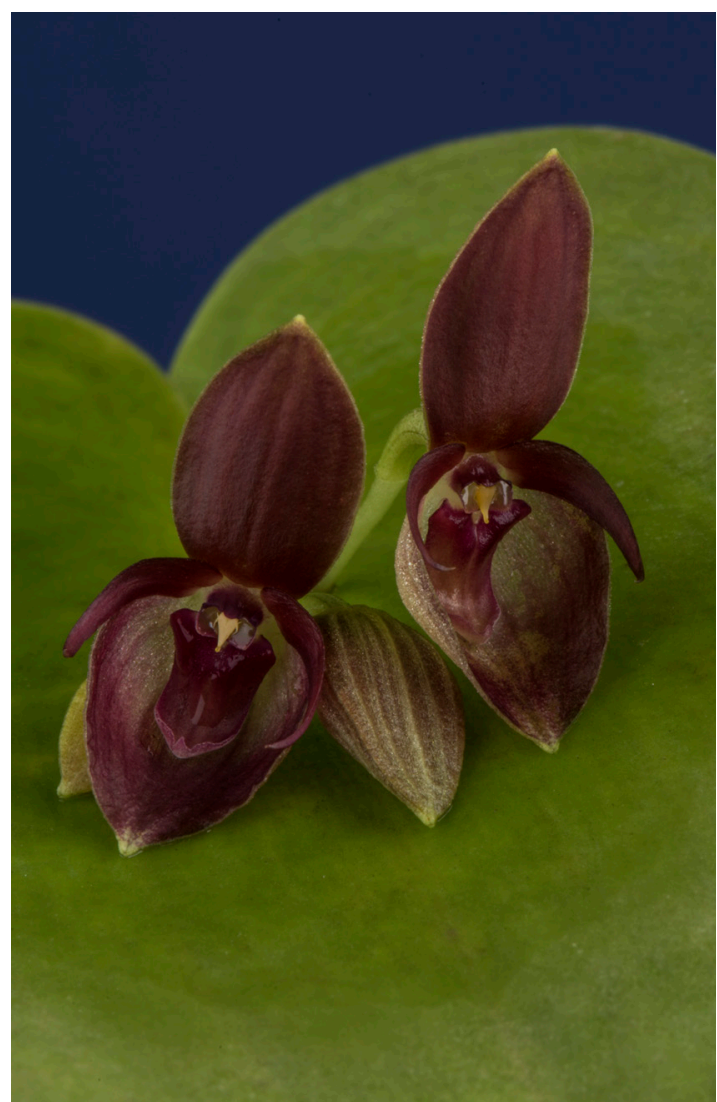

FIGURE 19. Flowers of the plant that served as the holotype of Pleurothallis navisepala. Photograph by F. Pupulin.
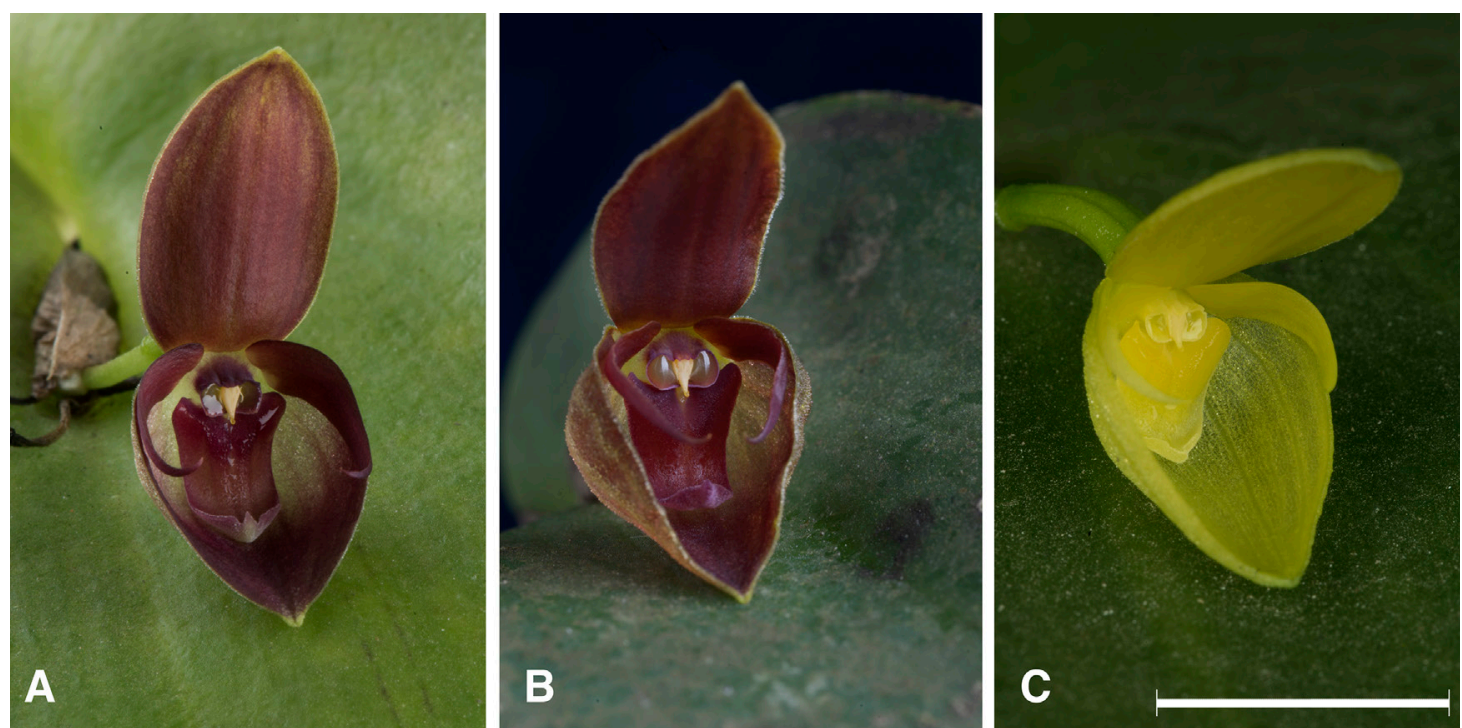

Figure 20. Flowers of Pleurothallis navisepala. A, Pupulin 8435. B, Pupulin 8028. C, Karremans 6793. Vouchers at JBL. Scale bar $=1 \mathrm{~cm}$. Photographs by F. Pupulin. 
Balsa, Reserva Biológica A.M. Brenes, 800-1000 m, 19 June 1995, flowered in cultivation at the Lankester Botanical Garden, 25 Sept. 2002, G. Carnevali \& A.C. Rodriguez s.n. under JBL-00787 (JBL); Balsa, San Ramón, 10 Dec. 1991, flowered in cultivation at the Lankester Botanical Garden, flowers yellow, 8 Sept. 2008, M. Freiberg s.n. under JBL-00787 (JBL); Costa Rica. Without specific locality, collected by D. Matamoros, 2010, flowered in cultivation at Jardín Botánico Lankester, 10 January 2011, F. Pupulin 8028 (JBL) (Fig. 20B, 21); without collecting data, flowered in cultivation at Jardín Botánico Lankester, 20 Feb. 1999, F. Pupulin 1342 (JBL); Alajuela: San Ramón, Ángeles, Balsa, road between San Ramón and La Fortuna de San Carlos, $10^{\circ} 10^{\prime} 03.6^{\prime \prime} \mathrm{N}$ 84²9'35.7'W, $1150 \mathrm{~m}$, epiphytic on trees in pastures close to Río Balsa, premontate rain forest, 29 May 2013, flowered in cultivation at Jardín Botánico Lankester, 4 Mar. 2016, F. Pupulin 8446, D. Bogarín, M. Díaz, \& M. Fernández (JBL); Alajuela: Upala, Bijagua. En la calle nueva desde el Celeste Mountain Lodge al parque Volcán Tenorio, en bosque primario al lado del camino, $10^{\circ} 43^{\prime} 00^{\prime} \mathrm{N} 85^{\circ} 01^{\prime} 23^{\prime \prime} \mathrm{W}, 783 \mathrm{~m}, 16$ Oct. 2015, flowered in cultivation at Lankester Botanical Garden, 19 Jan. 2017, A. P. Karremans 6793, I. Chinchilla \& E. Jiménez (JBL) (Fig. 20C); Upala, Bijagua. En la calle nueva desde el Celeste Mountain Lodge al parque Volcán Tenorio, orillas del bosque y potrero al lado del camino, $10^{\circ} 43^{\prime} 8.46^{\prime \prime} \mathrm{N} 85^{\circ} 0^{\prime} 2.07^{\prime \prime} \mathrm{W}, 729 \mathrm{~m}, 14 \mathrm{de}$ diciembre 2016, flowered in cultivation at Lankester Botanical Garden, 20 Feb. 2017, A. P. Karremans 7500, M. Cedeño, I. Chinchilla, M. Díaz \& G. Rojas-Alvarado (JBL); Alajuela: Upala, Bijagua, Zapote, desvío a la izquierda ca. $1 \mathrm{~km}$ después del puente sobre Río Zapote en sentido Bijagua-Pueblo Nuevo, Finca La Escondida, $10^{\circ} 45^{\prime} 21.0^{\prime \prime} \mathrm{N} 85^{\circ} 04^{\prime} 56.9^{\prime}$ 'W, 650-700 m, bosque muy húmedo tropical, transición a premontano, epífitas en bordes de potreros y árboles aislados de Citrus aurantium, 3 Febrero 2006, flowered in cultivation at Jardín Botánico Lankester, 26 Nov. 2011, D. Bogarín 2501, J. Barrantes, R.L. Dressler, R. Gómez \& A. Rojas (JBL); Guanacaste: Monteverde, $5 \mathrm{~km} N$ Santa Elena on road to Las Nubes, Finca San Bosco road, Río Negro, Atlantic slope, $10^{\circ} 22^{\prime} \mathrm{N} 84^{\circ} 49^{\prime} \mathrm{W}, 1400 \mathrm{~m}$, epiphyte on tree trunk, flower with sepals and petals yellow green, column light green, 10 November 1988, William Haber 8755 \& Willow Zuchowski (CR); La palma de San
Ramón, alt. $1175 \mathrm{~m}$, A. M. Brenes s.n. (CR); Alajuela: entre Balsa de San Ramón and the Río Cataratas or about $12 \mathrm{~km}$ north of Balsa, alt. 1100-550 m. Epiphytic dense shade, petals sepals green suffused with maroon, lip light maroon, some flowers much darker than anther, 27 January 1976, John and Kathy Utley 3779 (CR); Alajuela: Reserva Forestal de San Ramón, Cuenca del río San Lorencito, 900-1000 m. Epífita con flores amarillo-claro. Sépalos y pétalos incurvados. Sépalos brillantes, con estrías longitudinales. Labelo con el ápice triangular, con los bordes plegados hacia arriba en el ápice. Columna corta y muy ancha, en forma transversalmente rectangular, floreció 30/IX/1993 en Jardín Lankester, Cartago, 1350 m, Dora E. Mora s.n. (USJ); Guanacaste: Parque Nacional Guanacaste, Estación Biológica Volcán Cacao, Estación Pitilla, $10^{\circ} 55^{\prime} 45^{\prime} \mathrm{N} 84^{\circ} 28^{\prime} 15^{\prime \prime} \mathrm{W}, 1100 \mathrm{~m}$, epífita a 3m, flores rojas, 28 October 1990, Carlos Chávez 438 (USJ).

Etymology: From the Latin nave, boat, ship, and sepala, sepals, in allusion to the deeply concave, navicular synsepal, characteristic of the species.

Distribution: Known only from Costa Rica, where it has been recorded from the Caribbean watershed of the Cordillera de Tilarán and the Cordillera de Guanacaste (Fig. 13).

Habitat And eCology: Epiphytic in partial shade in mature vegetation, on thick branches and trunks covered with mosses. The species is apparently restricted to the northern mountain chains of Costa Rica, where it inhabits very wet premontane forests at elevations of 700 to 1200 meters. Flowering has been recorded from October to February, corresponding to the end of the rainy season and beginning of the dry season in the country. The flowers of $P$. navipetala are apparently very sensitive to changes in the humidity content of the environment, and a reduction of atmospheric humidity quickly lead to the incurving of the petals toward the column, followed by a partial to complete closure of the perianth. The flowers can open and close successively for five to six days, the daily time of complete spreading of the perianth depending on environmental condition, until they eventually fade, terminating the anthesis. According to our observations in the partially controlled environment of the Lankester Botanical Garden greenhouses, the flowers are more receptive (with the perianth fully spread) during the early morning. 


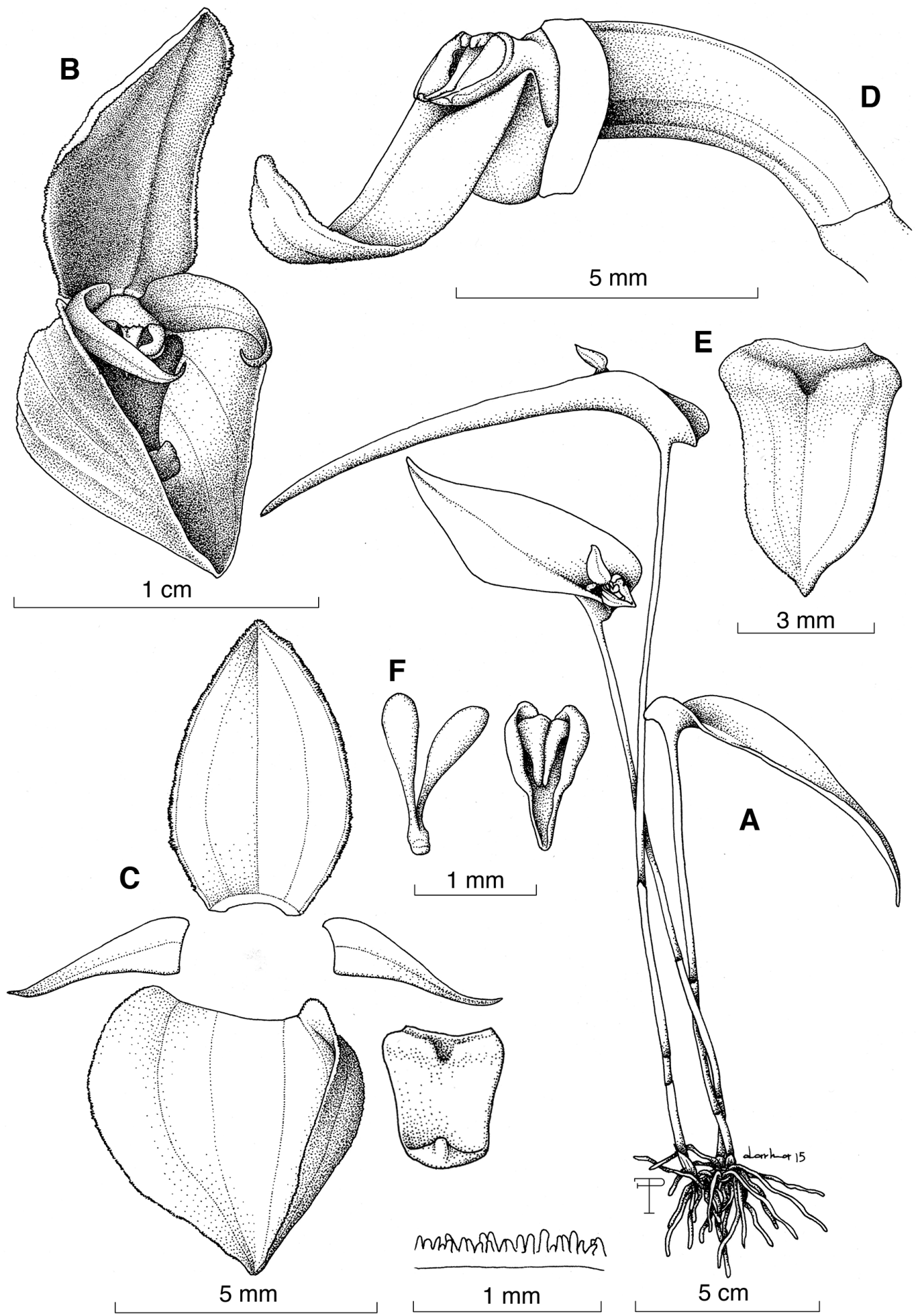

Figure 21. Pleurothallis navisepala. A, habit. B, flower. C, dissected perianth. D, column and lip, lateral view. E, lip, ventral view. F, pollinarium and anther cap. Drawn by Darha Solano Ulate and F. Pupulin based on F. Pupulin 8028 (JBL). 


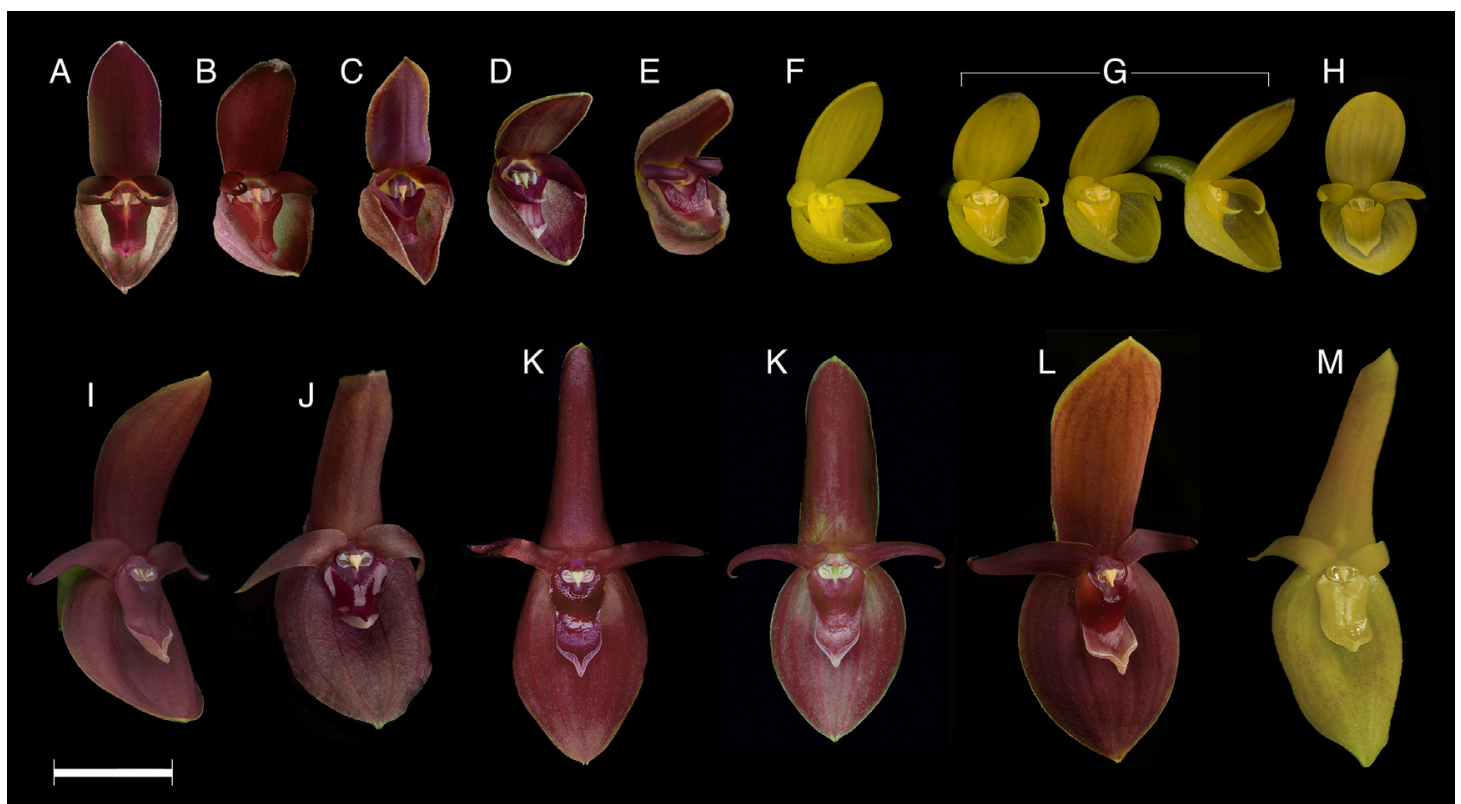

Figure 22. Comparison between the flowers of Pleurothallis navisepala (A-H) and P. cardiothallis (I-M). A, Pupulin 1342. B, JBL-00787. C, Pupulin 8028. D, Pupulin 8435. E, Pupulin 8434. F, JBL-02746. G, Karremans 6793. H, Karremans 7500. I, Dressler 6762. J, Karremans 7345. K, Blanco 2813. L, Karremans 6580. M, Pupulin 6414. Scale bar $=1 \mathrm{~cm}$. All the vouchers at JBL. Photographs by F. Pupulin.

Whilst large plants of $P$. navisepala are indistinguishable in habit from medium sized specimens of $P$. cardiothallis, the flowers easily allow distinction between the two species. In $P$. cardiothallis the flowers are produced singly, very rarely in pairs; they are large flowers for the genus, with the margins of the sepals and the petals reflexed at maturity. On the contrary, P. navisepala frequently produces two to four inflorescences at once, bearing comparatively small flowers that do not spread out completely, provided with a deeply concave-navicular synsepal and porrect petals (Fig. 22A-H). The size of the peltate lip is very similar between the two species, so that the ratio lip:synsepal is notably greater in P. navisepala, the lip occupying most of the concave space formed by the synsepal (Fig. 23). The synsepal is not ovate, but transversely elliptic-ovate. For this reason we prefer giving formal recognition to this taxon as distinct from P. cardiothallis (Fig. 22I-M), which has ovate sepals and a lip about half the length of the sepals (Reichenbach 1857).
As it is frequent with the complex of species close to $P$. cardiothallis, also P. navisepala presents two color morphs, one with purple flowers on a greenish white background (Fig. 22A-E), and another with solid, bright yellow flowers (Fig. 22F-H). In nature, the two color forms coexist in the same populations.

Auguste R. Endrés first collected and illustrated P. navisepala in 1869-1870 from a locality called "Legua de San Ramón” in Costa Rica (Fig. 24). Such a toponym does not exist more in modern Costa Rican maps, but it was likely located along the road traced to connect the village of San Ramón with the San Carlos plains to the north. Here Endrés worked for two years as a superintendent of the construction of the new road, and most of his orchid collections of that time probably originated from the upper portion of that road (Ossenbach et al. 2013). The supposed location of Endrés' collecting locality coincides with modern, documented findings of this species.

A Dipterian from the Tephritidae family was recorded visiting the flowers of $P$. navisepala early

$\Rightarrow$ Right, Figure 23. Comparison between the lips of Pleurothallis navisepala (A-B) and P. cardiothallis (C-D) in adaxial, three quarters, lateral, and abaxial views. A, Pupulin 8446. B, Karremans 6793. C, Karremans 6580. D, Blanco 2813. Scale bar $=1 \mathrm{~cm}$. All the vouchers at JBL. Photographs by F. Pupulin. 


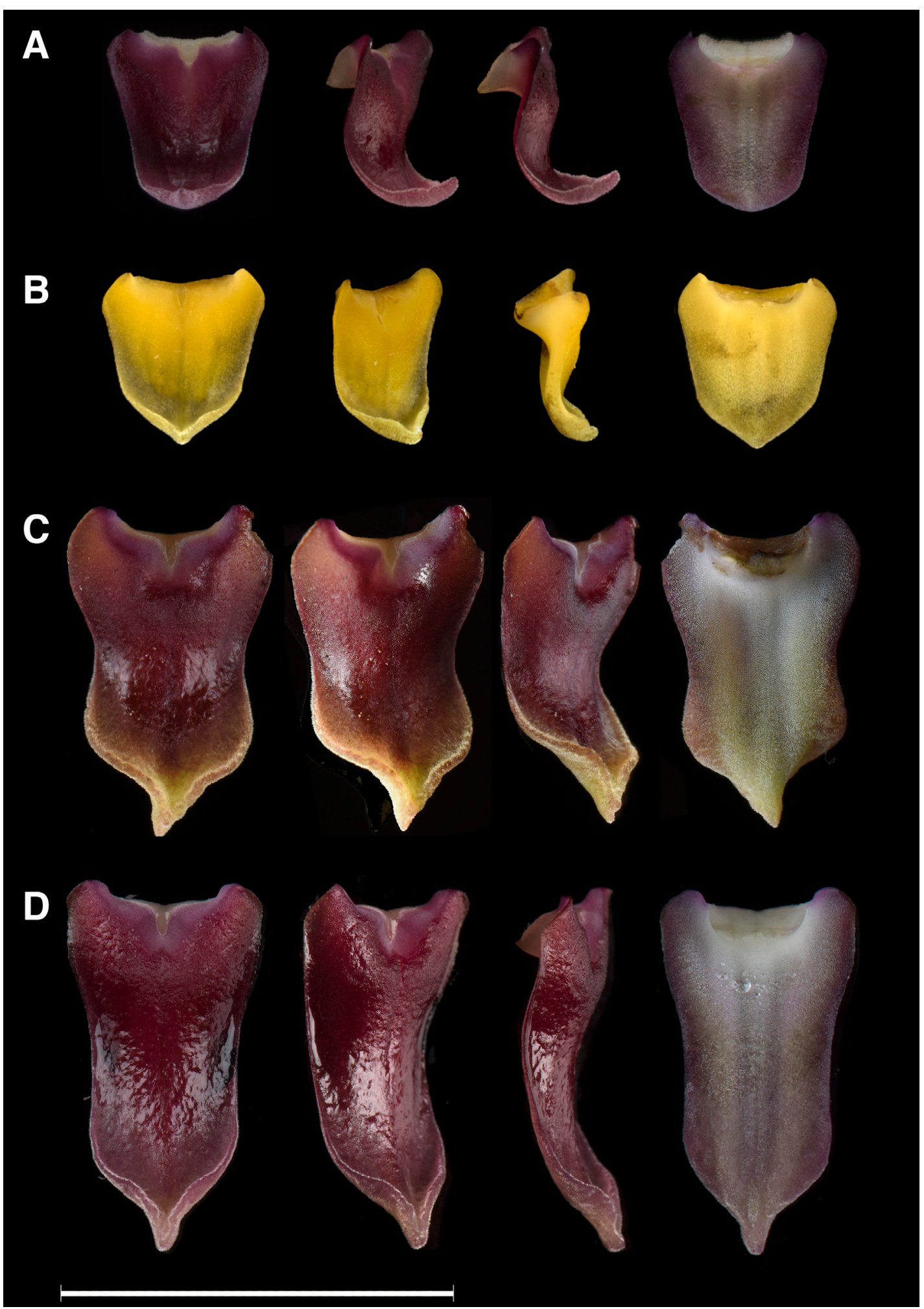




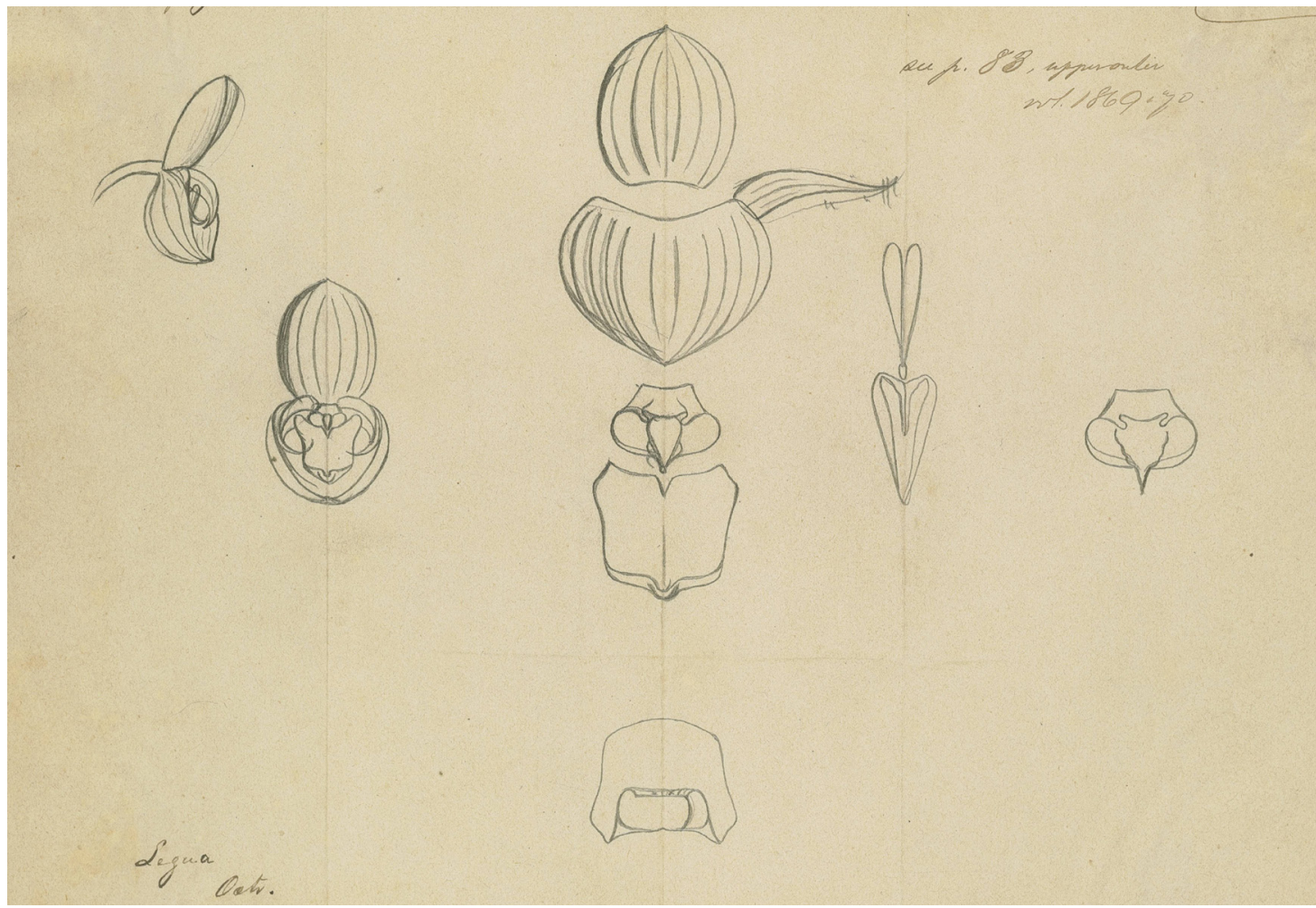

FiguRE 24. Drawing of Pleurothallis navisepala by A. R. Endrés (no. 52), from the vicinity of San Ramón, circa 1870.

Courtesy of the Director of the Herbarium, Natural History Museum, Wien.

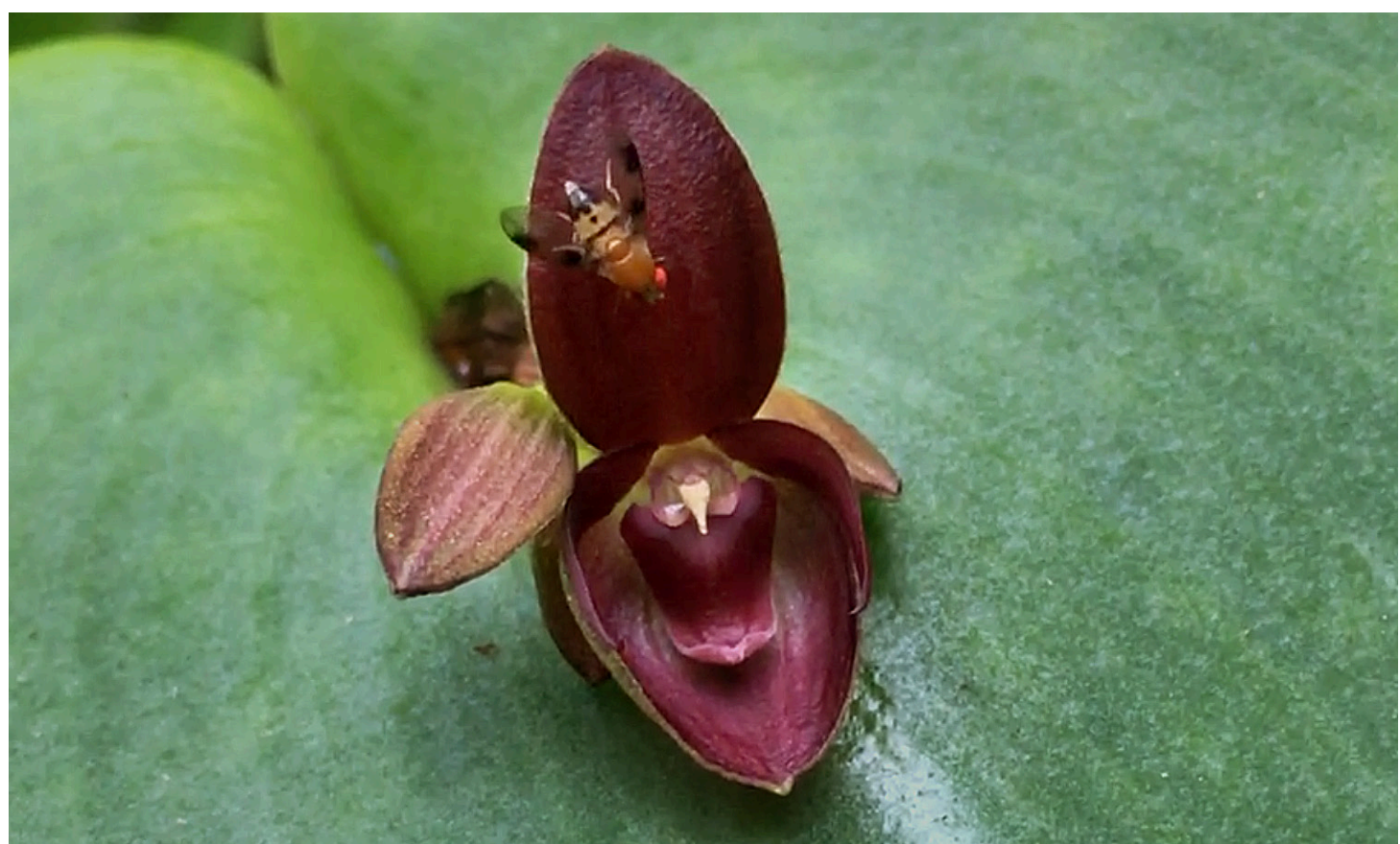

FigURE 25. Dipterian visiting the flowers of Pleurothallis navisepala (F. Pupulin 8028, JBL). Photograph by F. Pupulin.

LANKESTERIANA 17(2). 2017. (C) Universidad de Costa Rica, 2017. 
in the afternoon (Fig. 25). It landed on the adaxial surface of the dorsal sepal and walked on it making fast movements of the wings up and down while exploring the sepals. The up and down movements of the wings of the flies are associated to a mating behavior, however, this individual was observed by its self (Novak \& Foote 1975, Briceño \& Eberhard 2000). Effective removal of the pollinarium was not observed.

\section{Key to the SPECIES OF the $P$. CARDiothalLIS GRoup in Costa RicA}

1. Dorsal sepal deeply concave, much broader than the syncopal; lip suborbicular P. palliolata

1. Dorsal sepal slightly concave, sub-equal in width to the synsepal or narrower; lip triangular or peltate 2

2. Lip triangular

3. Flower solid dark purple, lip spread at apex

P. scotinantha

3. Flower pale purple, with the center yellowish white; apex of lip hooked

P. oncoglossa

2. Lip peltate

4. Flowers large, sepals $>10 \mathrm{~mm}$ long, produced singly, rarely in pairs; synsepal flat or slightly concave

P. cardiothallis

4. Flowers small, sepals $<7 \mathrm{~mm}$ long, produced several at once; synsepal deeply cymbiform

P. navisepala

ACKNOWLEDGMENTS. This manuscript was prepared as part of a dedicatory issue celebrating the ninety-fifth birthday of Carlyle A. Luer, in recognition of his outstanding work on the Pleurothallidinae. The scientific services of the Costa Rican Ministry of Environment and Energy (MINAE) and National System of Conservation Areas (SINAC) kindly issued the collecting permits under which wild specimens treated in this paper were collected. We are indebted to Diego Bogarín and Adam Karremans for the continuous and prolific discussion on the taxonomy and systematic of the Pleurothallidinae, and to Darha Solano Ulate for finely inking the illustrations. This research was enabled by the Project 814-A0-052, "Flora Costaricensis, Orchidaceae, subtribe Pleurothallidinae", supported by the Vice-Presidency of Research, Universidad de Costa Rica. Three anonymous reviewers greatly improved the previous draft of this manuscript with their valuable observations and suggestions.

\section{LITERATURE CITED}

Abdala-Roberts, L., Parra-Tabla, V. \& Navarro, J. (2007). Is floral longevity influenced by reproductive costs and pollination success in Cohniella ascendens (Orchidaceae)? Annals of Botany, 100(6), 1367-1371.

Aguiar, C. M. L., Santos, G. M. M., Martins, C. F. \& Presley, S. J. (2013). Trophic niche breadth and niche overlap in a guild of flower-visiting bees in a Brazilian dry forest. Apidologie, 44, 153-162.

Albores-Ortiz, O. \& Sosa, V. (2006) Polinización de dos especies simpátricas de Stelis (Pleurothallidinae, Orchidaceae). Acta Botánica Mexicana, 74, 155-168.

Ames, O. (1937). Orchidaceae. Pp. 1-63 in P. C. Standley \& B.E. Dahlgren (eds.). Flora of Costa Rica. Publications of the Field Museum of Natural History, Botanical Series, 18.

Ames, O. \& Correll, D. S. (1952). Orchids of Guatemala and Belize, vol. 1. Chicago: Chicago Natural History Museum.

Arens, P. (1923). Periodische Blütenbildung bei einigen Orchideen. Annales du Jardin Botanique de Buitenzorg, 32, 103124.

Barbosa, A. R., de Melo, M. C. \& Borba, E. L. (2009) Self-incompatibility and myophily in Octomeria (Orchidaceae, Pleurothallidinae) species. Plant Systematics and Evolution, 283, 1-8.

Blanco, M. A. \& Barboza, G. (2005). Pseudocopulatory pollination in Lepanthes (Orchidaceae: Pleurothallidinae) by fungus gnats. Annals of Botany, 95, 763-772.

Borba, E. L. \& Semir, J. (2001). Pollinator specificity and convergence in fly-pollinated Pleurothallis (Orchidaceae) species: a multiple population approach. Annals of Botany, 88, 75-88.

Borba, E. L., Semir, J. \& Shepherd, G. J. (2001). Self-incompatibility, inbreeding depression and crossing potential in five Brazilian Pleurothallis (Orchidaceae) species. Annals of Botany, 88, 89-99.

Borba, E. L., Barbosa, A. R., Melo, M. C., Gontijo, S. L. \& Oliveira, H. O. (2011). Mating systems in the Pleurothallidinae (Orchidaceae): evolutionary and systematic implications. Lankesteriana 11, 207-221. 
Briceño, R. D. \& Eberhard, W. G. (2000). Male Wing Positions during Courtship by Mediterranean Fruit Flies (Ceratitis capitata) (Diptera: Tephritidae). Journal of the Kansas Entomological Society, 73(3), 143-147.

Burkill, I. H. (1917). The flowering of the pigeon orchid, Dendrobium crumenatum. Gardens'Bulletin, Straits Settlements, $1,400-405$.

CaraDonna, P. J. \& Ackerman, J. D. (2010). Reproductive assurance for a rewardless epiphytic orchid in Puerto Rico: Pleurothallis ruscifolia (Orchidaceae, Pleurothallidinae). Caribbean Journal of Science, 46(2-3), 249-257.

Chase, M. W. (1985). Pollination of Pleurothallis endotrachys. American Orchid Society Bulletin, 54, 431-434.

Christensen, D. E. (1992). Notes on the reproductive biology of Stelis argentata Lindl. (Orchidaceae: Pleurothallidinae) in eastern Ecuador. Lindleyana, 7, 28-33.

Christensen, D. E. (1994). Fly pollination in the Orchidaceae. Pp. 415-454 in: Arditti, J. (ed.). Orchid biology: reviews and perspectives, Vol. 6. New York: John Wiley \& Sons.

de Melo, M. C. (2008). Biologia reprodutiva, variabilidade morfológica e micromorfologia floral de quatro espécies de Acianthera (Orchidaceae) ocorrentes em campos rupestres. (Masters degree thesis). Universidade Federal de Minas Gerais, Brazil.

de Melo, M.C., Borba, E.L. \& Paiva, E.A.S. (2010). Morphological and histological characterization of the osmophores and nectaries of four species of Acianthera (Orchidaceae: Pleurothallidinae). Plant Systematics and Evolution, 286, $141-151$.

di Vita, A. (2017). Hortus Orchis. Lepanthes scobariana. Available at: http://www.hortusorchis.org/en/botanicalorchids/117-1/1430-lepanthes-escobariana.html. Consulted February 2017.

Dressler, R. L. (1980). A checklist of the orchids of Panama as known today. Pp. i-xxvi in: Williams, L. O. \& and Allen, P. H. Orchids of Panama. A facsimile reprint of the Orchidaceae, Flora of Panama. Monogr. Syst. Bot. Missouri Bot. Gard., 4.

Duque-Buitrago, C. A., Alzate-Quintero, N. F., Otero, J. T. (2013). Nocturnal pollination by fungus gnats of the Colombian endemic species, Pleurothallis marthae (Orchidaceae: Pleurothallidinae). Lankesteriana, 13(3), 407-417.

Endara, L., Grimaldi, D. A. \& Roy, B. A. (2010). Lord of the flies: pollination of Dracula orchids. Lankesteriana, 10(1), $1-11$.

Gerlach, W. W. P. (1992a). Flowering behaviour of ephemeral orchids of Western Samoa: 1. Flowering periodicity. Gartenbauwissenschaft, 57, 219-222.

Gerlach, W. W. P. (1992b). Flowering behaviour of ephemeral orchids of Western Samoa: 2. Mechanism of anthesis induction. Gartenbauwissenschaft, 57, 288-291.

Hágsater, E., Soto Arenas, M. A., Salazar, G. A., Jiménez Machorro, R., López Rosas, M. A. \& Dressler, R. L. (2005). Las Orquídeas de México. México D. F.: Instituto Chinoín.

Hamer, F. (1974). Las orquídeas de El Salvador. The orchids of El Salvador. Die Orchideen El Salvadors. 2. San Salvador: Ministerio de Educación, Dirección de publicaciones.

Hamer, F. (1984). Orchids of Nicaragua. Part 4. Icones Plantarum Tropicarum, 11, pl. 1001-1100.

Hamer, F. (2001). Orchidaceae. In D. W. Stevens, C. Ulloa, A. Pool, \&and O. M. Montiel (Eds.), Flora de Nicaragua vol. 1. (pp. 1612-1853). St. Louis: Missouri Botanical Garden Press.

Hemsley, W.B. (1884). Orchidaceae. Pp. 197-308 in: F. D. Godman \& O. Salvin (eds.), Biologia Centrali Americana, 56 (Bot. 3). London, R. H. Porter.

Holttum, R. E. (1949). The gregarious flowering of the terrestrial orchid Bromheadia finlaysoniana. Gardens' Bulletin Singapore, 12, 295-302.

Huber, F. K., Kaiser, R., Sauter, W. \& Schiestl, F. P. (2005). Floral scent emission ad pollinator attraction in two species of Gymnadenia (Orchidaceae). Oecologia, 142(4), 564-575.

Internicola, A. I. \& Harder, L. D. (2012). Bumble-bee learning selects for both early and long flowering in food-deceptive plants. Proceedings of the Royal Society B: Biological Sciences, 279(1733), 1538-1543.

Jenny, R. (2015). Vanda stangeana, Consul Gustav Wilhelm Schiller and Franz F. Stange. Malayan Orchid Review, 49, 91-96.

Karremans, A. P., Albertazzi, F. J., Bakker, F. T., Bogarín, D., Eurlings, M. C. M., Pridgeon, A., Pupulin, F. \& Gravendeel, B. (2016). Phylogenetic reassessment of Specklinia and its allied genera in the Pleurothallidinae (Orchidaceae). Phytotaxa, $272,1-36$.

Kogler, S. (2010). Blütenbewegungen bei Bulbophyllum lobbii - Beschreibung der Bewegung und physiologische Grundlagen. (Magister degree thesis). University of Vienna, Austria.

Kolanowska, M. (2014). Orchids of the Darién Gap. Königstein: Koeltz Scientific Books. 
Lindley, J. (1859). Folia Orchidacea. An enumeration of the known species of orchids. Pleurothallis. Published for the author by J. Matthews, London.

Luer, C. A. (1996). New species in the Pleurothallidinae (Orchidaceae) from Costa Rica. Lindleyana, 11(2), 54-113.

Luer, C. A. (2005). Icones Pleurothallidinarum XXVII. Dryadella and Acronia Section Macrophyllae-Fasciculatae. Monographs in Systematic Botany from the Missouri Botanical Garden, 103.

Martini, P., Schlindwein, C. \& Montenegro, A. (2003). Pollination, flower longevity, and reproductive biology of Gongora quinquenervis Ruíz and Pavón (Orchidaceae) in an Atlantic forest fragment of Pernambuco, Brazil. Plant Biology, 5(5), 495-503.

Matile, P. \& Altenburger, R. (1988). Rhythms of fragrance emission in flowers. Planta, 174, 242-247.

McLeish, I., Pearce, N. R. \& Adams, B. R. (1995). Native Orchids of Belize. Rotterdam: Balkema.

Nielsen, L. J. \& Møller, B. L. (2015). Scent emission profiles from Darwin's orchid-Angraecum sesquipedale: investigation of the aldoxine metabolism using clustering analysis. Phytochemistry, 120, 3-18.

Novak, J. A. \& Foote, B. A. (1975). Biology and immature stages of fruit flies: the genus Stenopa (Diptera: Tephritidae). Journal of the Kansas Entomological Society, 48(1), 42-52.

Ossenbach, C., Pupulin, F. \& Jenny, R. (2013). Orchids in the life and work of Auguste R. Endrés. Volume 2. The illustrations and the catalogue. Vienna: Verlag des Naturhistorischen Museums Wien.

Pansarin, E. R., Pansarin, L. M., Martucci, M. E. P. \& Gobbo-Neto, L. (2016). Self-compatibility and specialization in a fly-pollinated Acianthera (Orchidaceae: Pleurothallidiinae). Australian Journal of Botany, 64(4), 359-367.

Parra-Tabla, V. \& Vargas, C. F. (2007). Flowering synchrony and floral display size affect pollination success in a deceitpollinated tropical orchid, Acta Oecologica, 32(1), 26-35.

Pérez Munguía, D. E. (2015). Orquídeas nativas de Honduras, Volumen 1. Tegucigalpa: Ediciones Ramsés.

Pridgeon, A. M. (2005). Subtribe Pleurothallidinae. In A. M. Pridgeon, P. J. Cribb, M. W. Chase \& F. N. Rasmussen (Eds.), Genera Orchidacearum. Volume 4 Epidendroideae (Part One) (pp. 319-422). New York: Oxford University Press.

Primack, R. (1985). Longevity of individual flowers. Annual Review of Ecology and Systematics, 16(1), 15-37.

Pupulin, F. (2007). Contributions toward a reassessment of Costa Rican Zygopetalinae (Orchidaceae). 3. A systematic revision of Dichaea in Costa Rica. Harvard Papers in Botany, 12, 15-153.

Pupulin, F., Karremans, A. P. \& Gravendeel, B. (2012). A reconsideration of the empusellous species of Specklinia (Orchidaceae: Pleurothallidinae) in Costa Rica. Phytotaxa, 63, 1-20.

Pupulin, F, Ossenbach, C., Jenny, R. \& Vitek, E. (2013). The Catalogue. Pp. 395-536 in: C. Ossenbach. F. Pupulin \& R. Jenny (eds.), Orchids in the life and work of August R. Endrés. Volume 2. The illustrations and the Catalogue. Vienna, Verlag des Naturhistorischen Museums.

Pupulin, F., Bogarín,D., Fernández, M., Díaz-Morales, M., Aguilar, J. \& Ossenbach, C. (2016). Orchidaceae Tonduzianae: typification of Costa Rican Orchidaceae described from collections of Adolphe Tonduz. Harvard Papers in Botany, 21(2), 263-320.

Ramos Cardoso, P. (2014). Desenvolvimento floral em espécies de Pleurothallidinae (Orchidaceae) com ênfase nas estruturas secretoras (Doctoral thesis). Instituto de Botânica da Secretaria de Estado do Meio Ambiente, São Paulo.

Reichenbach, H. G. (1857). Gartenorchideen, VI. Botanische Zeitung (Berlin), 15, 157-159.

Rolfe, R. A. (1892). CCXLVIII. New Orchids. Decade 2. Bulletin of Miscellaneous Information, Kew, 1892(65-66), 137-141.

Rolfe, R. A. (1917). New Orchids. Bulletin of Miscellaneous Information, Royal Gardens, Kew, 1917(2), 80-84.

Rothacker, E. P. (2007). The primitive Epidendroideae (Orchidaceae): phylogeny, character evolution and the systematics of Psilochilus (Triphoreae) (Doctoral thesis). The Ohio State University., Ohio.

Santos, G. M.M. \& Presley, S. J. (2010). Niche overlap and temporal activity patterns of social wasps in a Brazilian cashew orchard. Sociobiology, 56, 121-131.

Santos Fonseca, R., dos Santos, F. A. \& Faria Vieira, M. (2015). Is the pollination efficiency of the long-lived flowers of orchids affected by age? Capa, 62(4), 347-350.

Sayers, B. \& Adams, B. (2009). Guide to the orchids of Belize. Ireland: Cubola Productions.

Schlechter, F. R. F. (1912). Orchidaceae novae et criticae. Repertorium Specierum Novarum Regni Vegetabilis 10, 352-363.

Schlechter, F. R. F. (1918). Kritische Aufzählung der bisher aus Zentral-Amerika bekanntgewordenen Orchidaceen. Beihefte zum Botanischen Centralblatt, 36(2), 395-396.

Seifriz, W. (1923). The gregarious flowering of the orchid Dendrobium crumenatum. American Journal of Botany, 10(1), $32-37$.

Singer, R. B. \& Cocucci, A. A. (1999). Pollination mechanism in four sympatric southern Brazilian Epidendroideae orchids. Lindleyana, 14, 47-56. 
Smith, J. J. (1926). Ephemeral orchids. Annales du Jardin Botanique de Buitenzorg, 35, 55-70.

Srimuang, K., Watthana, S., Pedersen, H. Æ., Rangsayatorn, N. \& Eungwanichayapant, P. D. (2010). Flowering phenology, floral display and reproductive success in the genus Sirindhornia (Orchidaceae): a comparative study of three pollinatorrewarding species. Annales Botanici Fennici, 47, 439-448.

Stratton, D. A. (1989). Longevity of individual flowers in a Costa Rican cloud forest: ecological correlates and phylogenetic constraints. Biotropica, 21, 308-318.

van der Pijl, L. \& Dodson, C. H. (1966). Orchid flowers: their pollination and evolution. Coral Gables: University of Miami Press.

van Doorn, W. G. \& Kamdee, C. (2014). Flower opening and closure: an update, Journal of Experimental Botany, 65(20), $5749-5757$.

van Doorn, W. G. \& van Meeteren, U. (2003). Flower opening and closure: a review. Journal of Experimental Botany, 54(389), 1801-1812.

Vega Y. \& Marques, I. (2015). Both biotic and abiotic factors influence floral longevity in three species of Epidendrum (Orchidaceae). Plant Species Biology, 30, 184-192.

Went, F. A. F. C. (1898). Die Periodizität des Blühens von Dendrobium crumenatum Lindl. Annales du Jardin Botanique de Buitenzorg, 2, Suppl., 73-77.

Wiese, K. W. (2015). Riqueza de la familia Orchidaceae en la zona de visitantes del Parque nacional Cerro Azul Meámbar de Honduras. Lankesteriana, 15(3), 203-210.

Williams L. O. (1951). The Orchidaceae of Mexico. Ceiba, 2, 1-231. 